\title{
A Construção do 20 de Novembro: identidade Negra e afirmação na cidade de todas as gentes
}

\author{
Marco Aurélio Barbosa ${ }^{1}$
}

\begin{abstract}
Resumo: O seguinte artigo intitulado, "A Construção do 20 de Novembro: identidade Negra e afirmação na cidade de todas as gentes", centrar-se no debate que envolve a "negociação" em torno da construção do feriado do Dia da Consciência Negra em Curitiba. Desta feita, o trabalho tem como foco os debates ocorridos na Câmara Municipal de Curitiba, agentes ligados a interesses econômicos da cidade, notadamente, a Associação Comercial do Paraná (ACP) e Sindicato da Construção Civil do Paraná (SINDUSCOM-Pr) e os representantes do Movimento Negro em torno da questão. A abordagem leva tem em conta a altercação resultante da interdição do feriado, a ser comemorado pela primeira vez no ano de 2013. Interdição esta provocada pela ACP e SINDUSCOM-Pr, por medida judicial que levou a suspensão da comemoração, gerando revolta por parte do Movimento Negro e representantes da Câmara Municipal de Curitiba. Deste modo, o trabalho procura analisar de modo empírico os debates em torno desta questão, tendo em perspectiva os fatos anteriores ao eventos ocorridos em 2013 e seus desdobramentos até o ano de 2017, quando a disputa pelo feriado passa a ser discutida na Assembleia Legislativa do Paraná (ALEP). Cabe perguntar se houve alguma mudança em relação ao quadro apresentado em 2013? Se sim, quais? O que de fato está em disputa, quando leva em questão os interesses dos grupos envolvidos? Quais estratégias de afirmação adotadas pelo Movimento Negro na tentativa de se afirmar perante os outros grupos e deste modo conseguir a implementação do feriado?
\end{abstract}

Palavras-Chave: Consciência negra. Movimento Negro. ACP. Câmara Municipal de Curitiba. Feriado.

*Recebido em 30/05/2018.

*Aceito em 26/05/2018.

\section{INTRODUÇÃO}

No ano de 2013, decretou-se em Curitiba o Feriado da Consciência Negra ${ }^{2}$ tendo como data

1 Graduado em Sociologia pela Universidade Federal do Paraná (UFPR); Licenciado em História pelas Faculdades Integradas "Espírita" (UNIBEM); Especialista em Relações Étnico-raciais pelo Núcleo deEstudos Afro-Brasileiro da Universidade Federal do Paraná (NEAB-UFPR); Mestrando em Sociologia pela Universidade Federal do Paraná (UFPR). Email:barbosa.marco@gmail.com

2 A proposição desta data em caráter nacional foi formulada pelo "ativista e poeta negro Oliveira Silveira", que a teria sugerido em oposição ao dia Treze de Maio, que é tido por este como uma falsa data comemorativa, visto que esta data já era contestada pelo próprio movimento negro,uma vez que, segundo Silveira (2003), o Treze de Maio não satisfazia as necessidades do Movimento Negro e tão pouco os anseios da população negra, sendo assim, portanto, "não havia por que comemorá-lo. A abolição só havia abolido no papel; a lei não determinara medidas concretas, práticas, palpáveis em favor do negro. E sem o treze era preciso buscar outras datas, era preciso retomar a história do Brasil." Neste sentido, Oliveira Silveira teria sugerido em oposição ao dia Treze de Maio, o 20 de Novembro, onde justifica esta opção, apontando que: Circulava na época o fascículo Zumbi, o $\mathrm{n}^{\circ} 6$ na série Grandes Personagens da Nossa História, da Abril Cultural. Essa publicação fortaleceu no frequentador Oliveira Silveira a ideia de que Palmares fosse a passagem mais marcante na história do negro no Brasil. Um século de liberdade e luta contra o escravismo imposto pelo poder colonial português era coisa muito significativa e animadora. E lá estava o dia 20 de novembro de 1695, data da morte heroica de Zumbi, último rei e líder dos Palmares, marco assinalando também o final objetivo do Estado e país negro. (SILVEIRA,2003, P. 25) 
comemorativa o dia 20 de Novembro, entretanto, após forte pressão da Associação Comercial do Paraná ${ }^{3}(\mathrm{ACP})$, o mesmo foi suspenso.

Para tanto, utilizaram-se da via judicial, através de ação impetrada alegando o enorme prejuízo ao comércio da cidade, caso houvesse a parada, o que levou o judiciário a "cancelar" o feriado.

Os diversos grupos que representam o movimento negro, o Sindicato dos Trabalhadores do Comércio de Curitiba, Vereadores e a Câmara Municipal de Curitiba, buscaram intervir, com objetivo de alterar a situação, fazendo mobilizações nas ruas e interpondo recursos junto ao judiciário para a manutenção do feriado.

Contudo, acabou por ser derrotado nesta instância, o que impediu a comemoração efetiva da data, como fora originalmente proposta.

Por conta disto, a ACP foi acusada de racismo, por parte do grupo derrotado, por impedir um feriado inédito para este grupo.

Assim, o artigo centrar-se-á nos debates que envolvem a "negociação" em torno da Construção do Feriado do dia 20 de Novembro em Curitiba, na qual se acha em jogo o Dia Consciência Negra, importante feriado para o Movimento Negro.

Contudo, é importante destacar que o debate não se esgotou com a interdição do feriado, sendo este ainda, objeto de disputa e debate no campo jurídico e legislativo, isto é, o projeto ainda está em discussão no Supremo Tribunal Federal, bem como é objeto de arguições na Câmara Municipal de Curitiba.

\section{A Câmara Municipal de Curitiba frente ao 20 de Novembro}

Neste sentido, para fins de pesquisa foi utilizada a ferramenta de busca chamada Sistema de Proposição Legislativa - SPLII, que consiste em um portal com objetivo de dar transparência as ações dos Vereadores da Câmara Municipal de Curitiba, de tal forma que o usuário (cidadão) possa ter acesso aos trabalhos apresentados na Casa do Legislativo, onde pode se consultar informações sobre proposições, legislação, sessões plenárias, diários, comissões, instruções jurídicas, ofícios e informação ao cidadão, entre outros aspectos. Outras fontes utilizadas foram as publicações presentes

Salientando a importância simbólica desta comemoração que, tem como centro a figura histórica De Zumbi dos Palmares, símbolo de resistência e luta em favor da igualdade, seu principal elemento referencial para o Movimento Negro e a população negra, ensejando, ainda, uma discussão sobre a importância deste como herói nacional negro, inclusive com a reivindicação da adoção de um feriado em sua homenagem.

3 É importante salientar aqui, que havia a presença de outro importante ator a SINDUSCON- Sindicato da Construção Civil- que junto a ACP trabalhou no sentido de impedir a adoção do feriado, no que se opção apenas, pela Associação Comercial do Paraná, devido ao caráter e relevância tradicional e simbólica junto à sociedade curitibana e paranaense, entre outros aspectos. 
no site da Associação Comercial do Paraná, decorrente de notícias e periódicos publicados pela instituição.

Assim, para efeitos de pesquisa foram lançados nos sistemas acima apontados, as palavras chaves "Consciência negra, Movimento Negro, Câmara Municipal de Curitiba, Feriado" no intuito de ter acesso sobre o trâmite a movimentação destes órgãos e a posição dos Vereadores, ACP e Movimento Negro em relação ao tema aqui tratado. As palavras chaves utilizadas foram os termos Consciência Negra, que apontou 53 entradas e 20 de Novembro, com 576 entradas; foram analisadas as Notas Taquigráficas das sessões da Câmara de 2012 à 2016 onde foram discutidos o tema, bem como, as respostas e falas dos representantes da ACP, tanto na Câmara quanto em suas comunicações realizadas por meio institucionais próprios - site da ACP e Revista do Comércio - que foram lidas e filtradas no intuito de separar apenas aquelas, que tinham de maneira mais direta haver com o a pesquisa aqui proposta.

Deste modo, torna-se relevante abordar o papel desta instituição frente a este contexto, no intuito de melhor compreender esta situação é lhe tornar mais inteligível, assim, faz-se mister uma análise que contemple de modo empírica esta questão.

\section{Discussões e Proposições}

A primeira proposição a abordar o tema ocorre em 03 de Janeiro de 1988, por meio de projeto, proposto pela Vereadora Marlene Zanin ${ }^{4}$ e aprovado pelo então Prefeito Roberto Requião de Melo e Silva, no que dispõe que a data de 20 de Novembro seja consagrada a Zumbi dos Palmares, na qual dever-se-á realizar atividades voltadas a memória deste herói e celebração da cultura negra, a serem promovidas pela Fundação Cultural de Curitiba e Rede Municipal de Ensino, bem como, sessão especial na Câmara Municipal de Curitiba a ser celebrada anualmente, entretanto, como poderá se verificar, há um hiato de treze anos, até que o tema passe a ser objeto de debate na Câmara.

Após este hiato, a primeira proposição a abordar o tema ocorre em 20 de novembro de 2001 o Vereador André Passos ${ }^{5}$ (André Franco de Oliveira Passos) ${ }^{6}$, faz um requerimento de inserção nos

\footnotetext{
4 Marlene Zanin: natural de Urussanga, SC, nascida em 11/09/1955. Eleita em 15/11/1982 pelo PMDB, advogada de formação tomou posse em 01/02/19831. Foi secretária municipal do Meio Ambiente, coordenadora de Meio Ambiente e Cidadania da Copel e presidente da Comissão de Meio Ambiente da OAB-PR. Primeira presidente do Conselho Municipal da Condição Feminina.

5 André Passos Proposição no 055.00054.2001 de 20/11/2001 Fonte: SPLII disponível em: <http://www.cmc.pr.gov.br/wspl/sistema/ProposicaoDetalhesForm.do?select_action=\&popup=s\&chamado_por_link\&p ro_id $=184347 \&$ pesquisa $=20 \% 20 \mathrm{de} \% 20$ novembro $>$

6 André Franco de Oliveira Passos, natural de Curitiba, nascido em 10/06/1972, é filho de Edésio Passos, importante advogado trabalhistas brasileiro. É um dos idealizadores e fundadores do Instituto Edésio Passos, sócio-fundador e coordenador geral do escritório Passos \& Lunard Advogados Associados. Advogado formado pela UFPR, teve o início de sua carreira marcado pelo aprendizado e convívio com Edésio. Foi vereador pelo Partido dos Trabalhadores (PT) de
} 
anais da Assembleia a inserção de artigo vinculado pelo Jornal Gazeta do Povo, na sessão cultural Caderno G, publicado no mesmo dia do texto intitulado Zumbi nas Margens do Sul, escrita pelo jornalista Marco Zibordi.

O Vereador chama atenção para o fato do artigo fazer a importância histórica do 20 de Novembro para a sociedade brasileira, bem como, do papel do negro para Curitiba e o Brasil. Neste sentido menciona ainda, a questão do respeito a diversidade.

No que a ideia de feriado ou mesmo da criação deste, ainda, não se faz presente, por outro lado esta ação é uma tentativa que evidencia o Dia da Consciência Negra como algo relevante e passível de nota.

A segunda proposta verificada, foi o Projeto de Lei Ordinária de iniciativa do Vereador Reinhold Stephanes ${ }^{7} \mathrm{Jr}^{8}$, que busca Institui o "Dia Municipal da Consciência Negra", a ser comemorado no dia 20 de novembro, anualmente."Dia Municipal da Consciência Negra", a ser comemorado no dia 20 de novembro.

Ao propor o feriado o Vereador tem em seu horizonte a adoção Dia Nacional da Consciência Negra, instituído no dia 10 de Novembro de 2003, com o Decreto lei $\mathrm{n}^{\circ} 12.519$, que oficializa a data proposta pelo Movimento Negro em 1971 e divulgado nacionalmente em 1978.

Posteriormente, entre o período de 20 de Novembro de 2006 à 22 de Dezembro de 2008, tramitou o Projeto de Lei Ordinária desta vez por iniciativa do Vereador Manassés ${ }^{9}$ Oliveira ${ }^{10}$, outro

Curitiba por dois mandatos, de 2001 a 2008, tendo sido considerado nos dois mandatos o vereador mais atuante por sua assiduidade, transparência e importância nos projetos apresentados. Terminados os dois mandatos, optou por retornar à advocacia. Preside a Comissão de Direito Sindical da OAB/PR e é membro consultor da Comissão de Direito Sindical do Conselho Federal da OAB. É diretor de Assuntos Legislativos da ABRAT (Associação Brasileira de Advogados Trabalhistas).

7 Reinhold Stephanes Junior, natural de Curitiba, nascido em 26 de julho de 1965, é deputado estadual do Paraná filiado ao PSB. Filho de Marlene de Almeida e de Reinhold Stephanes. Formou-se em Economia pela Universidade Federal do Paraná. Possui especializações em Cultura e Democracia pelo Instituo Friderick Malman na Alemanha, Desafios da Liderança pela Universidade Federal do Rio de Janeiro e Oportunidades do Mercado Global pela Harward nos Estados Unidos. Foi Secretario Estadual de Administração. Foi eleito em 2000 vereador da cidade de Curitiba, sendo reeleito em 2004. Elegeu-se deputado estadual pela primeira vez em 2006, sendo reeleito em 2010. Em 15 de março de 2016 assumiu, como primeiro suplente, a cadeira do deputado Artagão Junior, que se licenciou, na Assembleia. 8 Reinhold Stephanes Jr - Proposição n ${ }^{\circ}$ : 005.00295.2005 de 10/11/2005 Fonte: SPLII Disponível em: <http://www.cmc.pr.gov.br/wspl/sistema/ProposicaoDetalhesForm.do?select_action=\&popup=s\&chamado_por_link\&p ro_id=34420\&pesquisa $=20 \% 20 \mathrm{de} \% 20$ novembro $>$

9 Manassés Oliveira da Silva, nascido em 19/06/1964 natural do município de Bandeirantes interior do Paraná, possui o Ensino Fundamental Completo. Manassés se elegeu vereador em 2005, tendo por base o movimento sindical e os movimentos populares. Foi diretor presidente do Sindicato e da Federação dos Empregados em Empresas de Asseio e Conservação do Estado do Paraná, também diretor de Comunicação da Federação Nacional dos Trabalhadores em Serviços, Asseio e Conservação, Limpeza Urbana, Ambiental e Áreas Verdes e secretário-geral da Confederação Nacional dos Trabalhadores em Empresas Prestadoras de Serviços a Terceiros. À convite do prefeito Beto Richa, em maio de 2007 assumiu Secretaria Municipal do Trabalho.

10 Manassés Oliveira - Proposição nº $n^{\circ}$ 005.00279.2006 de 20/11/2006 Fonte: SPLII Disponível em: <http://www.cmc.pr.gov.br/wspl/sistema/ProposicaoDetalhesForm.doselect_action=\&popup=s\&chamado_por_link\&pr o_id=2615\&pesquisa $=$ null $>$ 
projeto que propõe a adoção do feriado, desta vez, valendo-se de elementos históricos que evidenciam a importância e a participação da população negra na sociedade brasileira, recorrendo ainsa, a um breve histórico da data em questão. Chama ainda, a atenção para o “Art. $1^{\circ}$ - Inclui-se a Lei n ${ }^{\circ} 10.921$, de 18 de dezembro de 2003, o inciso VI, dispondo a seguinte redação: VI - Institui-se como Feriado Municipal o "Dia da Consciência Negra"., no intuito de buscar a aprovação de lei que fixe a ocasião como efeméride adicta ao calendário da cidade. Um ano mais tarde, em 18 de Novembro de 2009, a Vereadora Renata Bueno ${ }^{11}$ (Renata Eitelwein Bueno) ${ }^{12}$, solicitou a inscrição da data nos anais da Instituição, evento que tem importante relevância simbólica.

O período que se seguiu entre os anos de 2010 e 2013, mais precisamente entre 16 de Julho de 2010 e 21 de Janeiro de 2013, tramitou o Projeto de Lei Ordinária, de iniciativa do Vereador

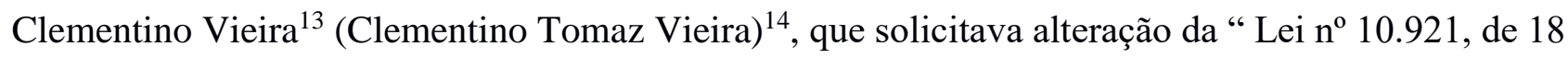
de dezembro de 2003, que dispõe sobre o combate ao racismo no Município de Curitiba e dá outras providências." para que passe a vigorar a seguinte redação conforme aponta o vereador:

\footnotetext{
Art. $1^{\circ}$ - $\mathrm{O}$ inciso $\mathrm{V}$ do artigo $1^{\circ}$ da Lei $\mathrm{n}^{\circ} 10.921$, de 18 de dezembro de 2003, passa a vigorar com a seguinte redação:

"V - institui o dia 20 de novembro como feriado municipal e "Dia da Consciência Negra" no calendário oficial do Município de Curitiba, em homenagem ao Dia Nacional da Consciência Negra."

Art. $2^{\circ}$ - Esta lei entra em vigor na data de sua publicação.”
}

Ao justificar a adoção da data e sua importância, alude ao fato de que este já é considerado como feriado em "757 municípios ( dos 5.564 municípios brasileiros) que já se sensibilizaram com a luta pela inclusão racial, comemorando a data com festividades específicas." e ainda, que "no Mato Grosso e no Rio de Janeiro, o feriado é estadual e, em 2008, o Mato Grosso do Sul também tornou o dia feriado em todos os municípios.”. ${ }^{15}$

11 Renata Bueno - Proposição $\mathrm{n}^{\circ}$ : 055.00027.2009 de 18/11/2009 Fonte: SPLII Disponível em: $<$ http://www.cmc.pr.gov.br/wspl/sistema/ProposicaoDetalhesForm.do?select_action=\&popup=s\&chamado_por_lin k\&pro_id=34896\&pesquisa=null $>$

12 Renata Eitelwein Bueno1 (Renata Bueno) natural de Brasília, nascida em 10/11/ 1979, foi vereadora entre os anos de 2009 e 2012. Presidiu, na Câmara de Curitiba, a Comissão Especial de Direitos Humanos e relatou a revisão da Lei Orgânica do Município (LOM). Graduada em Direito, elegeu-se deputada italiana pela União Sul-Americana dos Emigrantes Italianos, em 2013. Também é filha do Deputado Estadual Rubens Bueno (PPS).

13 Clementino Vieira - Proposição $\mathrm{n}^{\circ}$ : 005.00148.2010 de 16/07/2010 Fonte: SPLII Disponível em: <http://www.cmc.pr.gov.br/wspl/sistema/ProposicaoDetalhesForm.do?select_action=\&popup=s\&chamado_por_link\&p ro_id=65699\&pesquisa $=$ null $>$

14 Clementino Tomaz Vieira, nascido em 08/02/1963, natural de Curitiba, tomou posse como suplente do Vereador Algací Túlio em 08/06/2010, sendo este seu único mandato. Clementino tem sua origem no movimento sindical, no qual atua desde o final dos anos 80 . 
Já em 12 de Junho de 2012 tramita na Câmara projeto de Requerimento de Encaminhamento de Sugestão ao Executivo, encaminhado pelo Vereador Tico Kuzma ${ }^{16}$ (Leônidas Edson Kuzma) ${ }^{17}$, com autoria do Instituto 21 de Março - Consciência Negra e Direitos Humanos, que versa sobre a criação da Coordenadoria Municipal Especial de Políticas Étnico Racial ( COMEPER), que em projeto extenso e elaborado, aponta elementos relevantes e que justificam a criação de um órgão ou comissão junto à Prefeitura com objetivo de "formular, coordenar e articular as políticas públicas de promoção da igualdade substancial e da proteção dos direitos de indivíduos e grupos raciais e étnicos, com ênfase na população negra, afetados por discriminação racial e demais formas de intolerância."18.

Em relação ao feriado do 20 de Novembro, aponta como um de seus papeis “ Organização das atividades do feriado de 20 de novembro em conjunto com as secretarias da Educação, Cultura, Saúde, Esportes, etc ${ }^{19}$.”, de tal forma que apresenta este evento como ponto focal de conscientização e formação da população, bem como, salienta a importância da participação do poder publico através da Prefeitura e demais órgãos da municipalidade nesta incursão.

Como base de sua fundamentação cita o Congresso de Durban, A Carta dos Direitos Humanos, a Constituição Federal (Art. $3^{\circ}$, IV; Art. 208, IV) e a Lei Federal 12.288/2010 que dispõe sobre o Estatuto da Igualdade Racial, entre outros aspectos.

Outra proposta encaminhada foi o Projeto de Lei Ordinária de iniciativa de Tito Zeglin ${ }^{20}$, com autoria de Jonas Airton Miecznikowski ${ }^{21}$ do Gabinete do mesmo Vereador que tramitou entre as datas 20 de Novembro de 2012 à 04 de Janeiro de 2013, que propunha “a inserção da Festa da Igreja do

16 Tico Kuzma - Proposição no: 401.00024.2012 de 12/06/2012 Fonte: SPLII Disponível em:<http://www.cmc.pr.gov.br/wspl/sistema/ProposicaoDetalhesForm.do?select_action=\&popup=s\&chamado_por_lin k\&pro_id=212855\&pesquisa $=$ consciencia\%20negra $>$

17 Leônidas Edson Kuzma1 (Tico Kuzma), natural de Curitiba, nascido em 23/07/19712, é formado em Administração de Empresas. Em 2004, se elegeu vereador. Em 2006, foi candidato a deputado estadual, embora, não tenha eleito, ficou entre os dez mais votados na capital. Em 2008, foi reeleito vereador pelo PSB. No mesmo ano perde de mandato, em 09/08/2008, assumindo suplente Élcio José Pereira em 13/08/2008. No ano de 2010, foi candidato a deputado federal, ficando como primeiro suplente do PSB na Câmara dos Deputados. Em 2012, é reeleito para o terceiro mandato de vereador pelo PSB. No mês de outubro de 2013 passou a compor o Partido Republicano da Ordem Social (PROS). Nas eleições municipais de 2016, foi eleito para o quarto mandato (2017-2020) de vereador na Câmara Municipal de Curitiba. Para o biênio 2017-2018, Tico Kuzma foi eleito para o cargo de primeiro vice-presidente da Câmara Municipal de Curitiba.

18 Idem 16

19 Idem 16

20 Tito Zeglin natural de Mandirituba, nascido em 11/01/1954, foi eleito pela primeira vez em 1982. É um dos vereadores mais longevos da Câmara Municipal de Curitiba, tendo realizado nove mandatos, entre os anos de 1982, 1988, 1992 e 1996. Foi reeleito para o sexto mandato ao retornar em 2004, após ter ficado na suplência em 2000,3 desta forma assumindo os mandato 2005 e reconduzido ao cargo em 2009, 2013 e 2017.

21 Tito Zeglin - Proposição $\mathrm{n}^{\circ}$ : 005.00129.2012 de 20/11/2012 Fonte: SPLII Disponível em:<http://www.cmc.pr.gov.br/wspl/sistema/ProposicaoDetalhesForm.do?select_action=\&popup=s\&chamado_por_lin k\&pro_id=218057\&pesquisa $=$ consciencia\%20negra $>$ 
Rosário no Calendário Oficial de Eventos do Município de Curitiba, e dá outras providências.”, festa esta que deve ser celebrada no " final de semana mais próximo ao dia 20 , data em que se comemora o Dia de Zumbi dos Palmares, da consciência e da luta do povo negro." que chama atenção pelo seu caráter social e simbólico do evento que busca dar maior visibilidade à população negra da cidade, bem como, ao Dia da Consciência Negra.

Em outro momento, na mesma data em sessão realizada sobre a Presidência do Vereador Sabino Picolo ${ }^{22}$, o primeiro a tratar do tema do dia da Consciência Negra, foi o Vereador Zezinho do Sabará (José Ortiz Lins) ${ }^{23}$, que já no início desta sessão acusa para a Importância e faz referência à ocasião. Chama ainda atenção ao aproveitar a oportunidade para homenagear sua esposa, afrodescendente.

Entretanto, em seu discurso o Vereador ao apontar as conquistas relativas a população negra acabou juntar elementos diversos, primeiro aponta de modo justo a importância da data, fala da chega de um homem negro - Ministro Joaquim Barbosa - ao cargo de Ministro do Supremo Tribunal Federal e as cotas como uma conquista de toda a coletividade da população negra que tem sim, um importante marco simbólico para o Brasil e toda a população, sem contudo, aludir a expressão negativa e o embate propugnado pela oposição e determinados segmentos da sociedade que acabaram por expor em certos aspectos problemas raciais presentes até então ignorados/ escamoteados, tais como as claras diferenças de oportunidades entre brancos e negros, bem como, a luta jurídica e política em torno das cotas, e os episódios racismo que mais tarde o novo Ministro teria de enfrentar. Outra, questão tem a ver com a eleição de Barack Obama para a Presidência dos EUA, que embora tenha um caráter simbólico para os estadunidenses, nada mudou a realidade da população negra

22 Sabino Picolo, natural de Vitorino - PR, embora sua ficha no Tribunal Regional Eleitoral (TRE), o aponte como natural de Francisco Beltrão, nascido em 10/12/1950. Foi eleito Vereador pela primeira vez, em 1997, sendo reconduzido ao cargo em 2001, 2005, 2009, 2013 e 2017. Segundo informações contidas no perfil do vereador, no site da Câmara Municipal de Curitiba, "Sabino Picolo desde cedo trabalhou com a família na atividade agropecuária e, em 1976, por meio de concurso público, ingressou no Banco do Estado do Paraná S/A, o Banestado. É graduado em Ciências Econômicas pela Universidade Federal do Paraná (UFPR). Ainda estudante, deu início às atividades políticas. Foi eleito vereador pela primeira vez em 1996." É filiado ao DEM - Partido dos Democratas. Em 2001, foi designado como membro da Comissão de Urbanismo e Obras Públicas. Foi designado líder do prefeito em 05/08/2004. Tomou posse como terceirosecretário para o biênio 2007/2008 e foi eleito segundo-secretário para o biênio 2009/2010. Assumiu como primeiro vicepresidente para o biênio 2011/2012. Em 10/06/2011 assumiu o cargo de presidente da Câmara Municipal. Tomou posse em 27/01/2012, por motivo de ausência do titular, como prefeito de Curitiba. Por motivo de licença do titular, em 17/05/2012 assumiu interinamente o cargo de presidente do Legislativo. Em 29/11/2012, novamente por motivo de ausência do titular, assumiu a presidência da Câmara de Vereadores. Também encerrou o quarto mandato como titular da Comissão de Participação Legislativa. Em 2016, em matéria do Jornal Tribuna do Paraná foi listado entre os dez candidatos mais ricos, com um patrimônio de $\mathrm{R} \$ 5,1$ milhões.

23 José Ortiz Lins (Zezinho do Sabará), nascido em 01/07/1963, no município de Roncador, norte do Paraná. Foi agricultor, metalúrgico e comerciante. Atualmente exerce o cargo de Vereador, mora na Cidade Industrial de Curitiba (CIC). Foi dirigente de igreja, presidente de grêmio esportivo, associação de moradores e conselho de saúde. Editou jornal de bairro, foi comunicador e apresentador nas rádios Paraná, Colombo e Curitiba FM. Candidatou-se em três eleições para vereador em Curitiba. Como suplente tomou posse em 2011 a 2012. Em 2012 novamente ficou como suplemente. Em 2016, foi o quarto mais votado e o primeiro de seu partido, o PDT. Eleito em 2016, tomou posse em 2017. 
brasileira.

Em relação ao Vinte de Novembro o Vereador Tito Zeglin, chama atenção para o fato de que muitas vezes, a data passa despercebida.

Neste sentido, o Vereador destaca dois pontos importantes, primeiro que exite uma lei que versa sobre a participação anual em evento realizado na Câmara de Curitiba, no qual o espaço deve ser utilizado pelos representantes do Movimento Negro e Lideranças, para tratar sobre questões de cunho racial preconizados pela população por intermédio de seus representantes, mas, que não está sendo cumprida desde o ano de 1988, época de sua aprovação o que denota no mínimo uma “esquecimento" grave de uma lei que visa dar voz a um grupo tão esquecido da população, no que conclama a Prefeitura a tomar parte nesta tarefa e denota ainda, que a população negra faz a sua parte com eventos como a Lavação da Escadaria da Igreja do Rosário.

O Vereador Paulo Salamuni ${ }^{24}$, faz uso da palavra para aludir a data e assuntos correlatos como os apontados pelo Vereadores Zezinho do Sabará e Zeglin, para denotar a importância histórica destes eventos como marco civilizatório e de avanço para a sociedade.

Apesar deste fazer um discurso semelhante ao salientar determinadas qualidades morais e inclusive religiosas ligadas ao fato, compreende que o contexto social e no qual estes eventos se enunciam, buscando amenizar a situação apontando para as virtudes democráticas dos sistemas, que permitiram aos membros ada Câmara versarem sobre tais assuntos, no entanto, passando ao largo dos problemas já evidenciados, no breve debate aqui realizado em torno da fala do Vereador Zezinho do Sabará.

Na data de 21 de Novembro de 2012, em sessão presidida pelo Vereador Sabino Picolo, no $2^{\circ}$ turno da Sessão ocorrida na mesma data, quem preside o debate neste momento é o Vereador Tico Kusma, que ao saudar os presentes, chama à fala os presentes para tratar da questão do dia 20 de Novembro, dando a palavra ao Sr. João Luiz Cordeiro (João do Suco) ${ }^{25}$, que aponta a presença dos representantes do Movimento Negro entre os quais Dorival Simões, Presidente do Conselho Mediúnico do Brasil (CEBRAS) e representante da Associação Inter-religiosa de Educação ( ASSINTEC) e Adegmar José da Silva (Candieiro) do Projeto Humaitá.

João Luiz Cordeiro, prosseguindo a sua fala tece uma série de críticas ao racismo e aos

24 Paulo Salamuni, nascido em 24/10/1960, natural de Curitiba, filho do ex- Professor e Reitor da UFPR Riad Salamuni. Inciou a vida política sendo eleito para Vereador pela primeira vem em 1992. Eleito suplente em 1996, tomando posse em 1999, sendo reeleito para mandatos em 2001, 2005, 2009 e 2013.1 Em 2016, concorreu ao cargo de Vice-prefeito, na chapa encabeçada por Gustavo Fruet, que tentou a reeleição para Prefeito, cargo para o qual não foi reconduzido.

25 João Luiz Cordeiro (João do Suco)1, nascido em 09/06/1958, natural de Curitiba. Assumiu como em 2006, foi eleito em 2008. Foi um dos criadores da Associação Comercial do Pinheirinho (Ascomarp) entidade da qual é "presidente de honra". Ele também é membro do Conselho Estadual das Cidades, do Gabinete de Gestão Integrada Municipal em Segurança Pública - Pronasci, do Conselho do Hospital Erasto Gaertner e presidente do Comitê Curitiba do Movimento Nacional da Cidadania Pela Vida - Brasil Sem Aborto. 
racistas, bem como, ao preconceito sofrido pela população negra, no que ressalta a importância do respeito a pessoa, assim como, as suas crenças e costumes.

Chamado para exposição Candieiro, que faz uma breve análise das questões e problemas relativos a população negra, em especial no que toca a população negra curitibana, expondo dados estatísticos sobre a mesma, apontando que na cidade este grupo representa cerca de $23 \%$ da população da cidade e cerca de $30 \%$ da população paranaense configurando assim, a maior população negra entre os Estados da Região Sul, e que apesar desta representatividade populacional, sua voz ainda é pouco ouvida, sendo vítimas da invisibilização por conta das narrativas construídas em torno da identidade da cidade, por culpa do poder publico que apoia e se utiliza destas narrativas, bem como, aponta para as importantes figuras históricas negras da cidade e suas contribuições.

Salientou ainda, a importância do turismo religioso para a cidade, tendo em vista o número de pessoas atraídas pelo evento, buscando apontar exemplos em outros locais do Estado.

Posteriormente passou a palavra a Dorival Simões, representante da CEBRAS e da ASSINTEC, sendo este representante das Religiões de Matriz Afro, apontou para o nível de mobilização resultante do evento da Lavação, que atrai pessoas do Paraguai e Argentina, demonstrando assim, a importância internacional do evento, bem como a sua importância turística.

Reforçou a importância da presença da Municipalidade para a garantia da segurança de todos os envolvidos no evento, retornando ao assunto da falta de ação do poder publico no que toca a segurança relativa aos participantes do evento que não contavam sequer coma presença do departamento de trânsito para fechar as avenidas e garantir a boa dinâmica do evento. Após a exposição dos representantes dos Movimentos Sociais, seguiram-se as arguições por parte dos Vereadores, na qual a primeira a ter a palavra foi a Vereadora Prof. Josete (Josete Dubiaski da Silva) ${ }^{26}$, que destacou a presença dos representantes na casa e destacou o fato de as politicas afirmativas, terem tomado corpo durante por iniciativa do Governo Federal na figura do Presidente Luis Inácio Lula da Silva, com implementação da Lei 10639 de 2003 que implantou a obrigatoriedade do ensino de História e Cultura Afro e Indígena nas escolas de todo o país e a dificuldade de sua implementação.

Posteriormente, o Vereador Tito Zeglin, destacou a importância simbólica e cultural proporcionado pelo evento religioso da Lavação, bem como, destacou este local que fora em certa época campo santo - cemitério onde eram enterrados os negros escravizados - e portanto, importante marco para a população negra da cidade, fato que amplia a importância histórica e religiosa do local.

Candieiro, sentencia a importância da Lavação ter um caráter inter-religioso, uma vez, que

26 Josete Dubiaski da Silva (Professora Josete), nascida em 18/01/1964, natural de Curitiba no quarto mandato pelo Partido dos Trabalhadores(PT). Elegeu-se Vereadora pela primeira vez em 2005, sendo reeleita em 2009,2013 e 2017. É graduada em biologia. Ingressou na rede municipal de ensino em 1985 e, entre 1987 e 1994, também lecionou na rede estadual. Participou da criação do Sindicato dos Servidores do Magistério Municipal de Curitiba (Sismmac), o qual presidiu, e foi dirigente da CUT. 
neste se acham presentes representantes das várias vertentes religiosas que tem neste momento um espaço de representatividade.

Neste sentido, a Vereadora Maria Goretti (Maria Goretti David Lopes) ${ }^{27}$, evidencia o descaso do poder publico ao destacar que quando atuava na Secretaria de Saúde do Município houve um debate se existia ou não população negra em Curitiba para justificar uma "politica de enfrentamento da Anemia Falciforme - doença endêmica que atinge a população negra, pontuando e reforçando os dados estatístico, descritos por Candieiro, em um primeiro de sua fala, destacando ainda, a existência da Rede de Mulheres Negras do Paraná e sua importância. A Vereadora Julieta Reis (Julieta Maria Braga Côrtes Fialho dos Reis ${ }^{28}$ ), destaca a necessidade da ampliação da ação do poder publico em prol das atividades culturais relativas a população negra, criticando a pouca relevância dadas as estas expressões legitimamente nacionais frente, há outras estranhas a nossa cultura como o evento do Dia das Bruxas, por exemplo.

Neste sentido, muitas falas realizadas pelos Vereadores de modo geral, buscaram centrar-se na questão da representação da cultura negra em Curitiba, tratando de logradouros importantes como a Sociedade Treze de Maio, a Praça Zumbi dos Palmares e sobre o dia da Consciência Negra, tendo, no entanto, sempre como foco o evento da Lavação da Escadaria da Igreja do Rosário, sem contudo, principiar um debate sobre a criação de um feriado municipal para o Dia da Consciência Negra.

A sessão 26 de Novembro de 2012 é presidida pelo então Vereador João Luiz Cordeiro, ocasião na qual estava presente o ex- Vereador Clementino Tomaz Vieira e seus familiares, nesta ocasião este veio a Câmara, no intuito de propor e levar a votação do Feriado do 20 de Novembro, que foi apresentada e defendida pelo Vereador Algaci Túlio (Algaci Ormário Túlio) ${ }^{29}$.

A votação e apresentação foram realizadas durante a segunda sessão presidida pelo Vereador Tico Kuzma, nesta ocasião o Vereador Algaci Túlio solicitou a inversão da pauta, fazendo que o

27 Maria Goretti David Lopes (Maria Goretti): enfermeira, servidora pública e especialista em Desenvolvimento de Recursos Humanos, contribuiu para a criação do programa Mãe Curitibana. Ocupou a cadeira de João Cláudio Derosso na Câmara Municipal, entre julho e dezembro de 2012, na condição de primeira suplente do PSDB. Militante do movimento de mulheres, fundou a ONG Espaço Mulher, participou da coordenação do Comitê Multipartidário de Mulheres e é filiada à Rede Feminista de Saúde, Direitos Sexuais e Reprodutivos.

28 Julieta Maria Braga Côrtes Fialho dos Reis (Julieta Reis): nascida em 29/08/1947, natural de Curitiba. Elegeu-se pela primeira vez em 1997. Foi reeleita em 2001, 2005, 2009, 2013 e, em 2017 assumiu o sexto mandato consecutivo. Formada em artes plásticas, tem experiência junto à defesa da área cultural, idosos e microempresas. Servidora da prefeitura desde 1973, participou da criação da Fundação Cultural de Curitiba (FCC) e da Feira de Artesanato do Setor Histórico, também conhecida como Feirinha do Largo da Ordem.

29 Algaci Ormário Túlio (Algaci Túlio), nasceu em 08/12/1940, natural de Rio Branco do Sul, PR. Radialista e Jornalista, sua carreira política teve início com a sua primeira eleição em 15/11/1982. Tomou posse em 01/02/1983. Renunciou ao mandato em 31/01/1987 para assumir o mandato de Deputado Estadual, elegendo-se deputado estadual por quatro mandatos. Foi vice-prefeito de Curitiba por duas vezes, uma em 1988, quando integrou a chapa de Jaime Lerner, e dez anos depois em 1998, coligou-se a Cássio Taniguchi. Assumiu a prefeitura da capital por 29 vezes. Eleito em outubro de 2008 foi eleito vereador . Tomou posse em 01/01/2009. Em 2010,Algaci Túlio renuncia ao cargo de vereador e assume a Secretaria Especial do Estado do Paraná para assuntos da Copa 2014., em seu lugar toma assento o suplente Clementino Tomaz Vieira . Em 2012, Algaci Túlio, anuncia sua aposentadoria politica, após denuncia que envolvia seu nome relacionadas a pagamentos indevidos. 
assunto fosse apresentado antes dos demais, fato que aprovado após a apreciação e votação dos demais presentes.

Principiando sua fala sobre o tem, a do Feriado, o Vereador Algaci Túlio, aponta que faz a defesa da matéria proposta pelo ex-Vereador, pelo fato de que por conta desta condição esta impedido de fazê-lo, deste modo tomou a tarefa para si, frisando que [...] tenho a certeza absoluta que que esta Casa na sua totalidade vai votar favorável, não só pelo fato de que outras cidades já comemoram o 20 de novembro, mas em respeito aos nossos companheiros negros, nossos irmãos que merecem a igualdade [...] no que destaca ainda, o fato de existirem diversas cidades e Estados pelo Brasil que já adotaram a data em seus calendários.

No que chama atenção a presença do Ministério Publico, da Procuradoria Geral de Justiça, que são autoridades jurídicas que servem de endosso e apoiam declaradamente a adoção do feriado, bem como, de entidades ligadas à promoção da igualdade e representantes do Movimento Negro.

Ao terminar parte de sua exposição é congratulado pelos demais, no que toca a importância do projeto, no entanto, parece importante destacar a fala do Vereador Zé Maria ${ }^{30}$, que faz um conjunto de afirmações, que embora tenham um caráter lisonjeiro, apresenta um olhar contraditório da situação.

O depoimento do Vereador Zé Maria, aponta certa contrariedade, na medida em que ao parabenizar pela atitude o ex-Vereador Clementino ao propor a pauta do feriado, aponta que esta lei nem era necessária acreditando que o bom senso se faz por si só, apontando os EUA como um exemplo no que tocam as questões Étnico-Raciais tendo em conta a eleição de Obama para Presidente daquela nação, ignorando o debate histórico que esta suscitou, bem como, o passado - presente - de enfrentamento racial realizado naquela nação, a luta pelos direitos civis, e a ação enérgica por parte do Estado para que estes pudessem chegar a tal termo, na medida em que aponta a importância da obrigatoriedade do ensino de História e Cultura Indígena e Afro-brasileiras de caráter quase tópico, como apontara Candieiro ao referir-se a aplicação da mesma, fato que denota um certos desconhecimento dos problemas raciais enfrentados no Brasil e na própria cidade de Curitiba.

Posteriormente, a fala do Vereador Tito Zeglin, aponta para o fato de que outras cidades já estão adotando o feriado e assim como outros parlamentares ressalta a importância da data e meio a outras tantas, e em seguida faz uma observação interessante ao afirmar que; "A Associação Comercial, o comércio, estão preocupados que mais um dia estaremos parando. Vamos parar para quem sabe haja uma reflexão e que a gente possa acabar de vez com o racismo que ainda existe.

30 José Maria Alves Pereira (Zé Maria), nascido em 22/07/1958, natural de Pederneiras, SP. Foi eleito pela primeira vez em 2005 e, posteriormente reeleito em 2009 e 2013. É Maria Formado em administração de empresas. Foi candidato a deputado estadual em 2002 e em 2006. Foi presidente e atualmente é conselheiro da Escola de Educação Especial Primavera. É líder maçom. Atualmente sem mandato, segue gerenciando sua construtora, atividade que exerceu em paralelo, durante os anos de mandato. 
Muitos dizem que não, mas existe sim. É a contribuição do PDT, com o vosso pronunciamento.”, deste modo, justificando a necessidade da parada como um ponto de reflexão para a sociedade denotando e rebatendo as críticas feitas pela ACP.

Salamuni denuncia um telefonema recebido pelo Vereador Clementino, provavelmente em tom de ameaça, denotando uma situação clara de assédio.

Não apenas, se observa uma situação de assédio, mas, uma tentativa de interferência direta sobre a ação dos legisladores, buscando impor as preferências de certos grupos até aqui não identificados pelo parlamentar, que contudo, subtende-se a partir da fala de Salamuni que fala vez por outra em "associações" que tentam interferir nas ações do legislativo Municipal, e prossegue, "Curitiba não pode dizer, "ah, uma associação". Por isso a ninguém é dado o direito de pautar uma Casa que é heterogênea, idiossincrática, plural. Isso é uma questão que está acima desse ou daquele órgão. É uma questão de reflexão, é uma questão de marcar posição.”

A questão da ameaça ou tentativa de intimidação do ex-Vereador Clementino e novamente denunciada pelo Vereador Algaci Túlio.

Sendo complementado em seguida pelo Vereador Pedro Paulo (Pedro Paulo Costa) ${ }^{31}$, que reforça as posições de Salamuni e Algaci Túlio, reforçando que uma das condições que tornava possível este tipo discussão na casa, era propiciado pelo clima democrático.

Entretanto, a situação evidencia o contrário, já que a tentativa da imposição por membros da sociedade de suas preferências aos parlamentares, inclusive com telefonemas obscuros, que parecem atentar contra as regras do jogo político.

Todavia, a comoção gerada acabou por gerar um efeito rebote, que pode ser observado no ato da oposição ter aderido prontamente a adoção da efeméride, fato prenunciado pela Vereadora Noemia Rocha (Noemia de Souza e Silva Alves Rocha) ${ }^{32}$, que falando pelo grupo, afirma que, “A Oposição vai aprovar, já está de acordo com a aprovação deste projeto. Na verdade quero parabenizar tudo o que foi dito aqui. Está em concordância com tudo que pensamos.”, o que demonstra que havia uma resolução em torno da questão, provavelmente por conta do tipo de pressão que a Câmara Municipal estava enfrentando, bem como, para demonstrar seu lugar de poder frente ao demais grupos de poder na sociedade neste caso a ACP.

Algaci Túlio complementa esta ponderação ao asseverar que, “Com muito prazer também

31 Pedro Paulo Costa (Pedro Paulo), nascido em 04/07/1967, natural de Curitiba. Foi eleito suplente e assumindo o cargo de Vereador em 2003 e 2007. Eleito em 2008. Tomou posse em 2009 - 2013, foi líder de de Gustavo Fruet na Câmaraem 2012. Disputou a reeleição em 2016, não conseguindo renovar o seu mandato retornou ao magistério na rede pública municipal, onde ingressou em 1988. Atualmente, o ex-vereador leciona na escola de ensino fundamental, Albert Schweitzer, na Cidade Industrial de Curitiba (CIC).

32 Noemia de Souza e Silva Alves Rocha (Noemia Rocha). Nascida em 07/07/1961, natural de Londrina - PR. Foi eleita vereadora pela primeira vez em 2008 e reeleita em 2012 e 2016 vereadora do PMDB. 
acompanhar a discussão do seu projeto que é de suma importância. Muito obrigado a todos. Parabéns a Curitiba que vai, daqui a instantes, por unanimidade desta Casa, com certeza, aprovar dia 20 de novembro a data do Dia da Consciência Negra da Capital do Estado.”, no que se seguiu o processo de votação que confirmou, as posições dadas anteriormente, onde os Vereadores, votaram pela homologação da data.

No caso da sessão realizada em 27 de Novembro de 2012 é importante ressaltar que novamente está presente o ex-Vereador Clementino, que vem à Casa fazer uma fala sobre o projeto que versa sobre o combate ao racismo, ou seja, a Lei Ordinária no 005.00148.2010 que trata sobre a homologação do feriado da Consciência Negra, aprovado em $1^{\circ}$ Turno no dia anterior e que seria discutido em $2^{\circ}$ Turno na data em questão.

O Vereador Íris Simões (Iris Xavier Simões ${ }^{33}$ ), pede como solicitado na data anterior a inversão da pauta para que o tema fosse debatido primeiro, entretanto, o Presidente Sabino Picolo ressalta que o tema será discutido na hora oportuna, dando andamento a outras questões.

Posteriormente quando o tema vem a baila, a Vereadora Julieta Reis, solicita que a pauta seja votada somente daqui a dez sessões, isto é, só na próxima legislatura que seguiria, uma vez que, a votação se deu logo após as eleições municipais e o quadro de vereadores, bem como, o Prefeito seriam renovados, contudo, submetido a votação o requerimento foi negado, sendo o tema votado e aprovado em segundo turno, com um único voto contrário do Vereador Jair Cézar (Jair Cézar de Oliveira) ${ }^{34}$, que não conseguiu se reeleger na ocasião.

Chama atenção a presença do Representante da ACP Gláucio Geara, que vem a tribuna expor seus argumentos, dos quais não há registro nas notas desta sessão.

No entanto, em veículo de comunicação própria da ACP notifica que "Geara defende posição da ACP na Câmara Municipal”.

Neste sentido, este afirmou a preocupação da "entidade de classe do setor empresarial", em

33 Iris Xavier Simões (Iris Simões) nasceu em 25/05/1961, natural de Pato Branco,PR. É irmão, do radialista e exVereador Carlos Simões. Iniciou sua carreira política elegendo-se Vereador em 1993, sendo reeleito em Eleito em 1996. Renunciou ao mandato em 1999 para assumir o cargo de Deputado Federal, sendo em 2002 reeleito para o cargo. Em junho de 2006 foi declarado inelegível por três anos pelo Tribunal Regional Eleitoral (TRE) do Paraná por abuso de poder econômico e utilização indevida dos meios de comunicação social. Entretanto, recorreu ao Tribunal Superior Eleitoral (TSE), conseguindo ir ao pleito, sem no entanto, lograr exito. No pleito de 2008 candidatou-se ao mandato de vereador pelo Partido da República (PR), sofrendo nova derrota. Contudo, após ao falecimento da Vereadora Nely Almeida em 30/10/2012, Iris Simões assume a cadeira em 05/11/20122, nesta ocasião após a posse, o vereador anunciou a sua retirada do mundo político, encerrando sua carreira ao fim do mandato.

34 Jair Cézar de Oliveira ( Jair Cézar), nasceu em 05/11/19392, natural de Londrina, PR. É formado em Direito pela Pontifícia Universidade Católica do Paraná; em Turismo pela Universidade Federal do Paraná e é técnico em contabilidade pela Escola de Comércio de Londrina. Foi eleito vereador pela primeira vez em 1988, sendo reeleito em 1992, 1996, 2001, 2005 e 2009. Tentou a reeleição em 2012 e 2016,sem exito. Também é o fundador do Centro Cultural Vilinha do Bairro Alto, entidade sem fins lucrativos que visa a estruturação e implantação de um centro de artes no Parque Histórico da Vilinha, local onde se fixaram os primeiros colonizadores que deram origem à cidade. Na Câmara, apresentou vários projetos de lei que buscam destacar a arte paranaense. 
particular, uma preocupação co possíveis prejuízos causados por conta fechamento do comércio por ocasião da data, no que Geara tendo a permissão da Câmara para utilizar da palavra "advertiu os membros do legislativo sobre os prejuízos financeiros que os dias feriados provocam ao comércio, indústria e serviços, com a interrupção das atividades.".

O veículo da instituição aponta que:

O vice-presidente afirmou, ainda, que a entidade "não é contrária ao Dia da Consciência Negra e ao reconhecimento dos méritos de quaisquer etnias, mas tem a responsabilidade de advertir que mais um feriado num calendário repleto deles, certamente vai contribuir para o aumento das perdas financeiras dos empreendimentos, comprometendo seu desempenho na geração de emprego, renda e tributos".

Assim, o jornalístico aponta em certa medida para o conteúdo da fala do representante da ACP aos Vereadores e à Câmara, contudo, como se trata apenas de um recorte feito pela própria assessoria de comunicação da entidade, mas, que não poupou as palavras ao utilizar termos como "advertiu" ou ainda, "que tem a responsabilidade de advertir", se colocando como uma força frente aos representantes do Município, contudo, sem os registros de áudio ou notas taquigráfica, fica difícil aludir sobre o debate ali realizado.

Todavia, embora não haja registro nas notas da sessão do que foi dito pelo representante da ACP na sua integralidade, é possível inferir pelas falas do Vereador Paulo Salamuni, que este agiu de modo a tentar impor categoricamente a sua posição, sobre o tema.

[...] Mas, por falar em homenagem, aproveitando, quero fazer uma homenagem à Câmara Municipal de Curitiba pela votação do projeto anteriormente colocado em pauta. Uma coisa é nós, entre nós aqui divergirmos, brigarmos parlamentarmente, discordarmos, votarmos, isto é uma coisa, legitimo. Agora, o que não pode acontecer e aí é importante a humildade é entre uma votação e outra, qualquer grupo, qualquer instituição querer pautar a decisão de um Parlamento que é livre e é eleito democraticamente pelo povo, seja quem for. É óbvio que ouvimos e ouviremos a todos, como ouvimos com respeito os sindicatos, associações[...] Agora mesmo o Presidente do Sindimoc veio aqui, falou, ouvimos com respeito Como cada um irá votar é da consciência e do estilo e da personalidade de cada um. Agora, achar que tem mais associações ou tem menos associações, porque defende este ou aquele grupo. Então, a Câmara Municipal de Curitiba deu uma demonstração, não estou entrando no mérito, Sr. Presidente, porque podemos discordar do mérito e muitos que falaram: "Uma coisa é uma coisa, outra é outra”. [...]

A fala do Vereador Paulo Salamuni parece evidenciar uma posição agressiva da ACP, ao que tudo indica busca de maneira ferrenha demover os mesmos de sua posição, bem como, interferir incisivamente para a não aprovação do feriado. Mais à frente, Salamuni deixa o contexto mais claro, ao questionar a atitude intempestiva da ACP, que ao que tudo indica, veio a tribuna interferir na votação em segundo turno do projeto, a qual se apresenta como uma instância externa a lógica do jogo político, fato que o Vereador denota ao justificar a tentativa da Vereadora Julieta Reis de adiar a votação do projeto, atitude que aponta como aceitável em comparação a atitude da ACP, ao frisar que: 
[...] eu respeito a todos, inclusive o posicionamento muito coerente da Vereadora Julieta Reis que tentou o adiamento. Acho que é legítimo isso, mas de qualquer forma votamos ontem, seria muito complicado se a mídia, de uma associação poderosa ou seja lá quem fosse, seria um horror essa Câmara mudar o seu posicionamento porque alguém, entre o Primeiro e o Segundo Turno, veio aqui e de uma forma que pode ser interpretada de diversas formas pudesse mudar o rumo de uma votação. Abre um precedente perigosíssimo aqui. [...] Não estamos discutindo o mérito, mas é o processo legislativo, é o caminho das pedras que discutimos.[...]

Este trecho da fala do Vereador Salamuni, demonstra ainda, que a instituição buscou jogar seu peso para interferir e tensionar o processo decisório em andamento, entretanto, sem sucesso..

Neste mesmo dia em sua página na internet a ACP, traz à publico uma Carta Aberta feita pela instituição, na qual lê-se a chamada "ACP esclarece posição quanto a feriado da Consciência Negra" a nota aponta que no dia anterior a votação, Edson José Ramon, da Associação Comercial do Paraná (ACP), havia enviado uma carta aos membros da Câmara onde se coloca frente "ao projeto de transformação do Dia da Consciência Negra (20 de novembro) em feriado civil."

A carta se inicia em tom conciliatório, apontando e admitindo a importância do feriado, da data e do herói em questão, mas logo expõe ponto de vista da instituição, apontando que este "geraria sério e expressivo impacto negativo à atividade econômica e à atração de novos investimentos no município, além de redução na produtividade e crescimento de custos adicionais, comprometendo significativamente a capacidade e competitividade das empresas curitibanas de gerar empregos e tributos.", no entanto, sem demonstrar de forma cabal, isto é, por meio de planilha ou meio contábil, estatístico, comparativo, etc., qualquer elemento que desse causa à estas afirmações.

Apontou ainda que, a "entidade há anos desenvolve iniciativas para difusão da igualdade racial e promoção da cultura afro-brasileira, com atividades especialmente concebidas para o Dia da Consciência Negra.", embora, em uma pesquisa, mais profunda nos meios de comunicação da ACP, nenhuma menção a estas fosse encontrada.

Mais à frente a carta, aponta que a criação de um Feriado Da Consciência Negra seria uma forma de discriminação, uma vez que, "Ademais, a adoção desse feriado conferiria tratamento desigual a outras etnias que habitam a cidade de Curitiba, que igualmente fazem parte de sua história."

Procura ainda, denunciar que do ponto de vista da instituição a adoção do feriado é Inconstitucional, desconsiderando as leis que apoiam as chamadas politicas afirmativas em relação as populações negras e indígenas apontadas no Estatuto da Igualdade Racial.

Esta carta num sentido estrito acaba por se apontar como um ultimato à Câmara, na medida em que adverte que "Assim conclamamos aos nossos legisladores que não sejam adotadas iniciativas que signifiquem desincentivo à atividade empreendedora em nossa cidade e evitem que tal discussão chegue ao Judiciário."

No mês seguinte, a Câmara confere o título de Vulto Emérito, a Edson Ramon, o que pode interpretado diante da conjuntura política como uma tentativa de conciliação entre a Câmara e aCP. 
O evento foi noticiado na página da instituição no dia 11/12/2012, sob a chamada "Edson Ramon é Vulto Emérito de Curitiba", o jornalistico ainda desta que "o título Vulto Emérito de Curitiba, concedido pela Câmara Municipal na sessão especial realizada nesta segunda-feira (10)." sendo “A proposta aprovada por unanimidade pelo plenário da Casa teve a autoria do vereador Jair Cézar, e dentre as autoridades que prestigiaram o evento destacaram-se a presença do Prefeito Luciano Ducci, do deputado federal Eduardo Sciarra e, como representante do Governador Beto Richa, o secretário estadual da Copa Mário Celso. ${ }^{35}$,, o que denota um certo desejo da Casa em buscar uma saída política para a questão.

Contudo, a fala do Vereador Jair Cezar, buscou demonstrar apoio as ações da ACP, demonstrando seu apoio, no que a nota destaque "O vereador Jair Cézar destacou algumas das posições corajosas assumidas pela ACP, sob a liderança de Edson José Ramon, tais como o confronto com as elevadas tarifas de pedágio, as pichações e, recentemente, a aprovação do feriado da Consciência Negra no dia 20 de novembro. Sobre essa questão específica, o vereador reconheceu que “em nenhum momento o presidente Edson José Ramon se colocou contra a celebração da consciência negra, embora tenha se esforçado bravamente para evitar a aprovação de mais um feriado municipal”.

\section{O DEBATE GANHA CORPO}

O que se vê posteriormente é a cristalização das posições da ACP, quando esta anuncia em 16/01/2013, através de seus meios de comunicação institucional que "ACP estuda ação judicial contra feriado da Consciência Negra". A notícia aponta que ACP, com apoio do setor jurídico da instituição estava tomando providências no intuito de impugnar judicialmente a data, surgindo nesta pela primeira vez a "contabilidade" onde a "paralisação da atividade econômica traria um prejuízo calculado em R\$ 160 milhões para o município da capital.” sem no entanto, apontar um indicador que justificasse o valor auferido.

Por outro lado, Ramon aponta que "Entretanto, essas manifestações cívicas deveriam ser transformadas em eventos de natureza educativa, transmitindo às crianças e adolescentes, especialmente, a real compreensão da dimensão histórica desse herói nacional”, no evidencia seu ponto de vista e o da Instituição, ao apontar a desnecessidade de haver um feriado para a data em questão, mesmo em se tratando de um herói nacional.

Assevera ainda que "No momento oportuno, havendo respaldo na jurisprudência para o

35 Mario Celso Puglielli da Cunha (Mario Celso), nascido em 17/07/1946, natural de Curitiba.1É Jornalista Profissional e Radialista. Eleito vereador em 1976. Foi deputado estadual em 1978. Reeleito vereador em 1988, 1992, 1996, 2000, 2004 e 2008. Em 2010 escolhido como Líder do prefeito Luciano Ducci na Câmara Municipal. Em 2011 Convidado pelo Governador Beto Richa para assumir o cargo de Secretário Estadual para Assuntos da Copa do Mundo da FIFA 2014. No ano de 2013 Assumiu a Coordenação Geral de Eventos Esportivos da Secretaria Estadual do Esporte e do Turismo. 
ingresso da ação judicial a ACP tomará as medidas cabíveis, ressaltando que a preocupação não é menosprezar a honradez de pessoas trabalhadoras e ordeiras, mas simplesmente advertir para as perdas inevitáveis que a economia de Curitiba vai sofrer", no que faltou apontar quem eram as "pessoas trabalhadoras e ordeiras".

Posteriormente, em 17/01/2013, o site da ACP, anuncia que "Presidente da ACP se encontra com líderes de movimentos sociais", a reunião segundo informa o artigo foi uma iniciativa do então Presidente do Conselho Municipal de Política Étnico-Racial, Saul Dorval da Silva, do Vereador Adilson Alves Leandro (Mestre Pop-PSC), do advogado Mozart de Quadros foi uma tentativa de buscar junto ao então Presidente da ACP Edson José Ramon, não recorresse a via judicial, buscando sensibilizar este e a instituição a qual representa para importância simbólica da data para a população negra da cidade.

Segundo a notícia ocorreu "uma conversa amistosa, os representantes se prontificaram a apresentar estudos para comprovar que a paralisarão não trará prejuízos ao município, estimulando, inclusive, lucros em setores como o turismo e a gastronomia.", no que o Presidente da ACP acabou por reforçar as suas posições ao apontar que em nenhum momento "se manifestou contrariamente à legitimidade de prestar homenagens e reconhecer a importância histórica de Zumbi dos Palmares.”, insistindo que o feriado geraria prejuízos econômicos a cidade e que o mesmo deveria ser transformado em ponto para atividades educativas a serem realizadas voltadas para os estudantes, no intuito de celebrar a memória deste herói nacional.

A sessão de 18 de Janeiro de 2013 questão, marca o início de uma nova legislatura, marcada pela fala dos novos Vereadores que tomam posse de seus mandatos em virtude das eleições municipais ocorridas no ano de 2012, a mesma é presidida pelo Vereador Paulo Salamuni, que fora eleito para a função em vista do afastamento do antigo Presidente da Casa, João Claúdio Derosso ${ }^{36}$.

Dentre as falas de destaque que ocorrem nesta sessão é importante destacar a fala do Vereador Adilson Alves Leandro (Mestre Pop)", uma apresentação interessante, dado que este inicia sua exposição declarando sua origem e pertencimento racial, filho mãe negra e pai pardo, se colocando como homem negro (afrodescendente) frente aos demais representantes, ao que o Vereador Paulo Bernardes posteriormente chama atenção asseverando que, "Eu quero cumprimentá-lo, Vereador Mestre Pop. Durante vinte e seis anos fui vereador nesta Casa, vários colegas da raça negra estiveram aqui, mas hoje eu o parabenizo porque V.Exa. é o primeiro Vereador negro a levantar esta bandeira.”,

36 João Cláudio Derosso, nascido em 15/04/1957, natural de Curitiba e filho do ex-Vereador João Derosso. É formado em Engenharia Cartográfica pela Universidade Federal do Paraná e Administração pela Universidade Tuiuti do Paraná. Eleito par o seu primeiro mandato em 1989, reelegeu-se em 1993, 1997, 2001, 2005 e de 2009 a junho 2012. Seu ultimo mandato foi marcado por diversas denúncias de que Derosso também estava envolvido no escândalo aonde contratava a empresa de publicidade da própria mulher para desviar dinheiro público da casa. Em 2012, teve seu mandato de vereador cassado por infidelidade partidária. 
na medida em o novo parlamentar emite sua fala trazendo seu histórico de sujeito de ascendência popular e periférica, bem como, chama atenção para questões como o tratamento dado a população negra em Curitiba, a importância da adoção do Feriado do 20 de Novembro e atitude da ACP de impetrar ação na justiça contra a efetivação da data.

Neste sentido, a fala do Vereador Mestre Pop é eloquente e concisa, pois, toca em diversos problemas relacionados ao lugar ocupado pelo negro na cidade, do ponto de vista social, econômico e racial, bem como, o lugar periférico e marginal dado a esta população no que toca o trato dado aos seus problemas e necessidades, por outro lado chama atenção a crítica a justificativa econômica exposta pela ACP, para opor-se ao feriado, mesmo contra o interesse e aprovação por parte de $80 \%$ da população da cidade. Posição que segundo o Vereado se apoiava nos mesmos interesses financeiros que mantiveram e justificaram a escravidão no país até o final do Século XIX. Assim, esta fala chama atenção pela sua contundência e sobriedade como foi proferida.

Continua sua fala apontando para o preconceito que se acha enraizado na cidade, e aponta para as situações de discriminação pelas quais passou ao chegar a cidade, pelo desconhecimento dos espaços e por onde podia circular, e mesmo da sua persistência de se manter neste espaço apesar de tudo, retornado as suas críticas à interferência da $\mathrm{ACP}$, na tentativa de interditar a efeméride.

A fala do Vereador, expõe de modo visceral a seu ponto de vista sobre a atitude da ACP, de se interpor contra o poder publico em uma questão tão cara à população negra, que busca através da implantação do feriado, o resgate da contribuição do negro, para com a História do país e mesmo da cidade, que nega por meio do reconhecimento de outros grupos e etnias, a presença e a contribuição do negro para a cultura e a memória de curitibana. Por outro lado evidencia um desdem por parte da instituição ao generalizar e comparar a história pessoal de um membro da ACP, com a de um grupo marginalizado, procurando minimizar a questão por meio deste exemplo.

Neste sentido, o Vereador compreende esta ação e o processo impetrado pela ACP, bem como outras atitudes tomadas pela instituição, como racistas e que reproduzem uma moral escravocrata aonde a vontade do senhor de escravos era a lei. Sendo assim, se propõe junto ao Vereador Salamuni a agir em relação a oposição ao feriado, para que a data se cumpra.

No que Salamuni aponta para a força da Câmara ao resistir a pressão da ACP, dando ciência de como se deu a aprovação do feriado, bem como, a ausência do executivo, no que tange a sanção da lei, que acabou por conta de fato na responsabilidade do Presidente da Câmara.

No que Salamuni reforça, a constitucionalidade do projeto, aja vista que ouve uma análise e um debate sobre o tema, antes da aprovação do tema, por outro lado reforça uma vez mais o fato de que a população se achava pronta a apoiar o feriado, contudo, este não descartou a possibilidade da derrubada do mesmo, por conta de um movimento jurídico. 
O Vereador Tiago Gevert (Tiago Augusto Gevert) ${ }^{37}$, aponta reforça que não vê razão e/ou motivo para o questionamento da ACP, uma vez que, segundo o mesmo, [...] é fácil argumentar esta questão da ACP, pois o feriado da Consciência Negra não obriga que os comércios fechem. Então, não vejo necessidade que eles entrem com uma ação contra este feriado, porque ninguém está obrigando fechar nenhum comércio, nenhuma loja, nenhuma padaria, nada.”, esta afirmação aponta para a justificativa infundada por parte da ACP, sobre o prejuízo causado pelo fechamento do comércio que segundo este poderia trabalhar normalmente, não havendo razão na grita da entidade quanto a questão do feriado.

Vereador Jonny Stica (Jonny Magalhães Stica) ${ }^{38}$, aproveita o memento para questionar o modo como o povo e a história de Curitiba é representada, tendo em vista a pintura existente ao fundo do parlatório, onde se vê uma representação desta que não contempla a sociedade local.

Neste sentido, Salamuni evidencia que de fato de que estava presente quando da confecção da obra, e que de fato consistia num erro o fato desta não conter nenhuma representação que aludisse a população negra, mas, que no entanto, apesar desta não estar representada na obra, esta se fazia na presente na figura do Vereador Mestre Pop, que ocupava a tribuna, o que de fato se constituiu em uma elegante saída política para um problema visível, no que tanto Stica quanto Salamuni entendem que não se deve modificar a obra, consideração esta que poderia ser tensionada por qualquer representante do Movimento Negro.

Importante é apontar que tendo em vista a questão da data, o 20 de Novembro, outras atividades vinculadas a ela estavam sendo encaminhadas, como por exemplo o estabelecimento em calendário oficial da cidade da Festa da Lavação da Escadaria da Igreja do Rosário.

Tito Zeglin, com autoria de Jonas Airton Miecznikowski propõe projeto de lei orçamentária em 5 de Fevereiro de 2013 que tramita até a data de 25 de Abril do mesmo ano, em novamente “ Dispõe sobre a inserção da Festa da Igreja do Rosário no Calendário Oficial de Eventos do Município de Curitiba, e dá outras providências.”, em que ligam o evento de modo direto ao Dia da Consciência Negra.

Por outro lado a ACP, manteve-se mobilizada no que toca a sua oposição a comemoração fato

37 Tiago Augusto Gevert (Tiago Gevert) nascido em 09/04/1986, natural de Curitiba. Exerceu um único mandato que durou de 2013 à 2016. Entretanto, o ex-Vereador continua trabalhando nos bastidores da política, uma vez que, “está lotado na $1^{a}$ vice-presidência da Casa, ocupada pelo deputado Guto Silva (PSD). Segundo Gervert, suas atribuições no novo cargo envolvem a articulação política para o grupo que integra - ligado ao secretário de Desenvolvimento Urbano, Ratinho Junior (PSD). Para isso, o ex-vereador recebe, mensalmente, R\$ 19,5 mil, de acordo com o Portal da Transparência da Assembleia. Gevert afirma que também está construindo sua candidatura ao cargo de deputado estadual, em 2018.", segundo o Jornal Gazeta do Povo.

38 Jonny Magalhães Stica (Jonny Stica) nasceu em 10/10/1983, natural de Curitiba, é filho do ex-vereador e ex-deputado estadual Natálio Stica. Foi eleito pela primeira vez em 2008. Tomou posse em 2009, sendo reeleito para um segundo mandato2 em 2013. Em 2016 disputou um terceiro mandato, no entanto não foi reeleito. Atualmente é dono e administrador de um escritório de arquitetura, atuando na área de projetos residenciais e edifícios, conforme aponta o Jornal Gazeta do Povo. 
que torna mais evidente esta posição tem a ver com artigo publicada na Revista do Comércio, de publicação trimestral da própria ACP na edição número 166 de Fevereiro / Março de 2013 traz em si dois artigos, no primeiro na sessão "Palavra do Presidente", Edson Ramon assina o texto intitulado “Comemoração não é sinônimo de feriado", onde defende a "desnecessidade" da parada na data.

Logo em suas primeiras palavras informa que “[...] a Associação Comercial do Paraná (ACP) assumiu de forma coerente com seus princípios históricos uma posição de inconformismo com a criação em Curitiba do feriado da Consciência Negra, a ser comemorado no dia 20 de novembro.”, ou seja, nada novo, mas não se pode deixar de refletir sobre qual tradição esta afirmativa se estabelece, uma vez, que o próprio Barão do Serro $\mathrm{Azul}^{39}$ foi um dos primeiros à por-se ao lado dos abolicionistas no Estado do Paraná.

O Presidente da instituição contínua sua exposição argumentando a tentativa de convencer os Vereadores, que obstante aos interesses da associação aprovaram por unanimidade a adoção do Feriado, no que buscaram então "sensibilizar" o então Prefeito Luciano Ducci “que preferiu não se pronunciar sobre o mérito da questão, devolvendo-a a Câmara. Nos primeiros dias da atual legislatura, a citada Casa promulgou a lei instituindo o feriado em homenagem a Zumbi dos Palmares." o que denota um certo quadro de indiferença dos gestores contra a grita da ACP e seus representantes. Neste sentido, a associação retoma a sua fala sobre respeito a comunidade negra, etc., mas que no entanto, estabelece uma estratégia para por meio da via judicial interditar o mesmo, por meio de uma Ação Direta de Inconstitucionalidade (ADIN).

Mais, a frente na mesma edição uma chamada, denota que ACP não ficou apenas nas palavras, partindo de fato para o embate, como lê-se no título da mesma "ACP ingressa com ação contra feriado", notícia que é reproduzida no institucional da ACP em 07/02 do mesmo ano, nesta o informativo deslinda as ações da instituição no sentido de avançar na interdição do feriado.

No que buscam ainda, balizar sua visão sobre o feriado, apontando para possíveis jurisprudências, que tem como estofo ações propostas por Goiais, Santa Catarina e Rio Grande do Sul, sendo que as duas últimas, assim como o Paraná pertencem a Região Sul do Brasil que possuem um longo histórico de negação e invisibilização das populações negras em nome de um discurso de “europeidade". Neste sentido parece importante destacar que a associação aponta que:

A Adin em foco faz também referência à jurisprudência firmada pelos tribunais de Justiça de Goiás, Santa Catarina e Rio Grande do Sul, que consideraram inconstitucionais leis municipais que pretendiam instituir o feriado da Consciência Negra nos municípios de Goiânia, São José, Porto Alegre, Pelotas e Alvorada. Dessa forma, a peça jurídica deixa claro que "há razões suficientes que demonstram falta de apoio legal e constitucional à pretensão do estabelecimento de mais um feriado sob a égide municipal", acentuando que o dia 20 de novembro já é reconhecido pela lei federal n. 12.519/11 como "Dia de Zumbi e da Consciência Negra", sem ser declarado feriado. 
No que repete novamente seu epiteto ao afirmar que:

De acordo com a ACP, a entidade, em momento algum, se manifestou contrariamente à legitimidade de prestar homenagens e reconhecer a importância histórica de Zumbi dos Palmares, e se declara apoiadora de eventos que transmitam à população a real compreensão histórica desse herói nacional.

A esta altura a ACP estabelece como padrão este argumento que é repetido como uma espécie de "mezinho" para afugentar as exprobrações de que sua ação seria racista, como afirmaram vários dos Vereadores ao apontar a intromissão desta nas decisões tomadas na Câmara, ações que acabaram por acirrar os ânimos na casa.

Deste modo, a instituição ainda afirma, que o intuito da Adin seria corrigir uma suposta extrapolação do papel do Legislativo Municipal.

Ainda, no mesmo informativo, na sessão "G.2. Tribunal de Justiça do Estado do Paraná", vêse novamente o tema, sob o título "FERIADO - DIA DA CONSCIÊNCIA NEGRA", dá-se a conhecer o número da Adin, uma reprise das queixas da instituição, porém, uma olhada mais atenta chama atenção para o fato da instituição ter em sua revista uma coluna dedicada a acompanhar diretamente as questões relativas ao andamento de temas jurídicos de interesse da desta e seus associados, o que indica uma grande grau de racionalidade no controle das ações e ambientes de poder pela ACP.

Em 07/02/2013 ao republicar em sua página rede a reportagem “ACP ingressa com ação contra feriado da Consciência Negra" em 07/02/2013, a instituição repete em grande parte o discurso produzido em sua revista, porém, com certas "novidades" ao agregar novos dados como o montante do alegado "prejuízo" gerado pela possível parada do 20 de Novembro, desenvolvendo um raciocínio simples para explicar o dano causado pelo feriado, bem como, nomina as demais associações envolvidas na luta contra o feriado e possivelmente na impetração da Adin.

O que se percebe é a unificação e/ou a criação de um conglomerado de associações ligadas ao comércio e industrial em variados setores liderados pela ACP, no ataque ao feriado, no sentido de pressionar os vereadores e o Prefeito, para que não houvesse uma promulgação da data, onde vê-se a mobilização causado pelo tema nos meios empresariais e o esforço presente nesta articulação.

Posteriormente, em página institucional da instituição, em 06/05/2013 informa que "ACP continua tentando na Justiça derrubar feriado da Consciência Negra", retornando aos temas já aludidos anteriormente, voltando a conjurar as mesmas formulas e discursos anteriormente mobilizados.

Mais tarde em Agosto do mesmo ano, em sua Revista do Comercio, o editorial produzido por Edson Ramon, faz de maneira um tanto subjetiva para tecer críticas as instituições, em texto denominado "Ética em primeiro lugar" em que principia sua fala a tocar na questão dos valores mantidos pela instituição “[...]Associação Comercial do Paraná, entidade representativa de milhares 
de empresários do comércio e serviços, estou convicto de que a Casa do Barão do Serro Azul soube honrar o histórico acervo de ações em defesa da ética, livre iniciativa e, especialmente, da moralidade na gestão pública, entre outros valores da cidadania.”, Grosso modo, o que Edson Ramon aponta é a instituição como elementos basilares ou como exemplo de "civilidade" perante a sociedade, e que por conta seria uma espécie de guardião desta.

Neste sentido, o Presidente da ACP, continua seu discurso nas entrelinhas, se referindo aos embates por esta travados, apontando para um período importante para o evento aqui analisado, uma vez, que expõe de certa forma o esforço desta de impor a sua agenda frente as autoridades, entre eles o embate em torno do Dia da Consciência Negra, embora não fosse o único item presente em sua agenda.

No que o feriado do 20 de Novembro, parece figura como problema a ser atacado, e ser enfrentado em nome da ética.

Finalmente em 04/11/2013, a ACP lança a nota com o título "Feriado da Consciência Negra é suspenso pelo TJPR" na qual aponta que o julgamento da Adin realido no STJ-Pr, havia chegado a um termo, sentenciando que:

Por 17 votos a cinco foi deferida a Medida Cautelar em Ação Direta de Inconstitucionalidade (Adin), ajuizada pela Associação Comercial do Paraná (ACP) e Sindicato da Construção Civil do Paraná (Sinduscon-PR), determinando a suspensão dos efeitos da lei que instituiu o feriado municipal do Dia da Consciência Negra, no próximo dia 20 de novembro. A medida foi tomada pelo órgão especial do Tribunal de Justiça do Paraná (TJPR), em sessão realizada na tarde dessa segunda-feira (4).

Feito este comunicado, no dia seguinte $(05 / 11 / 2013)$ a ACP, soltou nova nota em seu site afirmando que "ACP diz que TJ respeitou o princípio federativo", no que retoma parte do conteúdo já informado, ao esclarecer que os representantes do TJ-Pr, votou por unanimidade em favor da ação apresentada pela associação, apontando ainda, seu caráter provisório, concedendo liminar em favor da ACP e Sindicato da Construção Civil do Paraná (Sinduscon-PR), derrubando ainda que provisoriamente a data.

No que torna a proclamar de modo quase que automático, aquilo que profere os mesmos "dísticos" tal e qual ao "feiticeiro e sua magia", ao afirmar que:

\footnotetext{
“A ACP não se coloca em posição contrária à comemoração cívica e histórica da data, mas não abre mão da atitude democrática em defesa dos interesses da sociedade", acrescentou Sarmento. A evocação da consciência negra e da enorme contribuição do povo afrodescendente ao desenvolvimento econômico e social, que deveria ser tema obrigatório nos currículos escolares, não necessita de um feriado para ser lembrada, concluiu o presidente.
}

Dito de outra forma, o que os representantes da ACP fazem ao repetir os mesmo mantra sobre a importância da data, mas, não obstante e em ato se oporem a ela dizendo-se favoráveis, o que longe aquilo que poderia se compreender como uma contradição, na medida apresenta o elemento da 
eficácia simbólica, isto é, como uma espécie de xamã ao conjurar certas fórmulas que possuem certo valor social e valorados por sua posição social- pelo menos do ponto de vista do que representa a instituição - legítima, legitimante e legitimada por estes estatutos e confere um força à priore a seus argumentos que por isto acabam por ter afirmados a sociedade, evitando possíveis questionamentos, na medida em que desmobiliza ou tem poder de sujeitar simbolicamente outros sujeitos aos seus interesses.

Neste sentido evidencia manipulação da realidade ou do olhar sobre a realidade como meio de legitimar o poder, evitando assim qualquer tipo de dissenção e/ou revolta dos grupos excluídos.

Isto é, este tipo de argumentação a exemplo do que evidencia Jessé Souza sobre a legitimação de certos grupos privilegiados este, aponta que na sociedade pré-moderna onde os privilégios, mesmo que injustos, eram expostos abertamente e justificavam-se por uma moral divina a qual todos estavam sujeitos, deste modo evitando qualquer tipo de questionamento mais aprofundado dos mesmos, no entanto, após o advento da construção da sociedade moderna com seu ideal de igualdade de abolição dos privilégios injustos, estes não podem mais aparecer, desta forma precisa-se criar algo que os justifique e os legitime, tornando-os em algo "merecível".

Deste modo:

É isso que faz com que o mundo social seja sistematicamente distorcido e falseado. Todos os privilégios e interesses que estão ganhando dependem do sucesso da distorção e do falseamento do mundo social para continuarem a se reproduzir indefinidamente. A reprodução de todos os privilégios injustos no tempo depende do p"convencimento", e não da "violência". Melhor dizendo, essa reprodução depende de uma "violência simbólica", perpetrada com o consentimento mudo dos excluídos dos privilégios, e não da "violência física". É por conta disso que os privilegiados são os donos dos jornais, das editoras, das universidades, das TVs e do que se decide nos tribunais e nos partidos políticos. Apenas dominando todas essas estruturas é que se pode monopolizar os recursos naturais que deveriam ser de todos, e explorar o trabalho da imensa maioria de não privilegiados sob a forma de taxa de lucro, juro, renda da terra ou aluguel. (SOUZA-2015, p.9-10)

Este fato pode ser denotado, quando o representante da ACP, se utiliza da ideia de que a justiça ao determinar a interdição da efeméride acabou por atentar aos princípios da cidadania, os quais a instituição defende, que comemoração não significa feriado, e que embora a data seja importante deveria haver uma leis que a tornasse obrigatória sua discussão no espaço da escola, esquecendo que a proferida lei já exite, procurando disfarçar seus interesses falando do prejuízo econômico e pela comunidade, utilizando-se da voz coletiva que não lhe pertence e do parecer jurídico respaldado pela liminar.

Frente a esta situação o representante da ACP, Camilo Turmina, comparece à Câmara Municipal de Curitiba, para tratar de algumas propostas e demandas que pretende apresentar ao Vereadores em 11 de Setembro de 2013

A reunião é Presidida pelo Vereador Paulo Salamuni, nesta ocasião está presente o representante da ACP, para fazer um a parte na Tribuna Livre, espaço concedido aos membros da 
sociedade para exporem suas demandas frente a Câmara, neste caso, Camilo Turmina, vice presidente do Conselho de Câmaras Setoriais da Associação Comercial do Paraná, por convite do Vereador Helio Wirbiski, para tratar de uma campanha promovida pela mesma, sobre o nome "Despiche Curitiba", isto é, um projeto que visa tratar sobre a questão das depredações promovidas por pichadores na cidade.

Entretanto, é importante salientar que durante a fala o membro da ACP, versará sobre vários assuntos tais como: horário de abertura e fechamento do comércio, os problemas viários e de transporte urbanos enfrentados pela cidade, a proposta de fechamento do comércio no horário dos jogos da Copa e a questão dos feriados, tendo em vista, como não poderia deixar de ocorrer o sueto do 20 de Novembro.

Onde Turmina, liga as posições da ACP, a um ato de cidadania ao opor-se aos feriados, uma vez que, são um impeditivo ao funcionamento das atividades econômicas, gerando ônus e prejuízo ao comércio.

No que, parece relativizar e ao mesmo tempo generalizar o feriado da Consciência Negra, com eventos anuais como o Carnaval e outros pontuais como a Copa do Mundo sediada no Brasil, entre outros eventos, chegando a comparar e/ou sugerir que estes eventos se oferecem como uma oportunidade de gazeta por parte dos trabalhadores.

Mais à frente em um debate que discute uma limitação de tempo para a tramitação e/ou resposta a aprovação ou veto de um projeto o tema retorno, com um colorido interessante, na medida em que no bojo da discussão se pode apreender como se deu uma parte do debate sobre a questão decisória relativa a aprovação do feriado. Estas questões se fazem presentes nas falas de vários vereadores, contudo, o Vereador Valdemir Soares (Valdemir Manoel Soares) ${ }^{40}$, ao tratar da questão da tramitação oferece uma explicação sucinta.

O Vereador aponta que, mais importante ou tão importante quanto ao prazo é o concerto entre as partes, no que para que o projeto seja aceito ou mesmo para que tenha a probabilidade de sê-lo é necessária antes de mais nada o trâmite nas instâncias necessárias, bem como, a já citada anuência dos entes, o que por óbvio faz com que as emendas de antemão sejam chanceladas ou refutadas, o que indica que a aprovação é previa e pode ser prevista, contudo, mesmo isto não garante que as partes honrarão o acordo.

Neste caso, é o que se vê na fala de Paulo Salamuni a respeito da questão do feriado, onde este aponta para o funcionamento da instituição, ou seja, as consultas necessárias foram feitas, inclusive com a anuência do Prefeito, que na ocasião era Luciano Ducci, que havia acenado em favor

40 Valdemir Manoel Soares (Pastor Valdemir Soares), nasceu em 01/12/1972, natural do Rio de Janeiro. Foi eleito Vereador pela primeira vez em 2000, posteriormente reeleito em 2004, 2009, 2013. Em 06/04/2016 renunciou após ser filmado votando por outro colega, sendo substituído pelo seu suplente Edson do Parolim em 18/04/2016. 
do feriado e se comprometido a sancioná-lo, contudo, surge outra personagem neste debate que é a $\mathrm{ACP}$, que ao que tudo indica questionou não apenas os Vereadores, mas, ao excecutivo diretamente que diante desta retirou a palavra, por outro lado, vê-se o nível de inserção da instituição e sua capacidade de colocar-se frente ao mundo político. Outro elemento passível de análise é uma certa hesitação presente na fala do Vereador, apontando para o fato de que o tema "não foi conversado o suficiente" e que o mesmo foi aprovado por conta da ação do Prefeito que depois decidiu não agir, e da pressão do Conselho de Política Étnico Racial que exigiu que o tema estivesse na pauta, e por uma questão regimental e tendo os meios aprovou, mas, que no entanto, caso houvesse uma ordem judicial para a interdição do feriado esta poderia ser acata, o que dito de outra forma pareceria até uma sugestão, não fosse o fato do Vereador ter feito uma defesa enfática da liberdade da Casa em arbitrar em nome da população prerrogativa da qual dispunha para se colocar frente a ACP e da qual esta se valeu para se contrapor a esta.

Há ainda o Requerimento de Realização de Audiência Pública proposto em 07 de Outubro de 2013, pela Vereadora Professora Josete, que tem como escopo "Requer à Mesa na forma regimental, a realização de audiência pública na data de 22 de novembro de 2013. Tema: Dia da Consciência Negra." na qual se buscou avaliar as politicas públicas adotadas em relação a população negra, tendo como interlocutores os "Representantes do Movimento Negro de Curitiba, Membros da Secretaria Municipal do Trabalho e da Secretaria Municipal de Educação.”

Alguns meses mais tarde em 05 de Novembro de 2013, o tema da Consciência Negra retorna à Câmara por meio do Vereador Mestre Pop.

Nesta sessão após as considerações iniciais feitas pelo Presidente da Casa, o Vereador Mestre Pop, inicia sua fala, fazendo uma ponderação sobre a presença negra em Curitiba, tendo em vista a participação destes na construção da cidade, chamando atenção para vultos importantes como o Engenheiro André Rebouças, destacando ainda, o fato desta ser a "a cidade mais negra do Sul do Brasil”, no que toca a proporção da população negra comparada a outros Estados, buscando através do apontamento das questões relativas a esta população chamar a tenção para a forma desigual como ela é representada e mesmo tratada.

Neste sentido aponta a questão do feriado como um elemento de resgate histórico destas populações, apontando para o preterimento desta frente aos demais grupos étnicos, fazendo alusão a ACP e aos seus questionamentos por parte desta contra aprovação da data comemorativa ligada a população negra.

O que Pop busca é chamar atenção para o que está em jogo e o que deseja a população negra, fazendo uma reflexão sobre a igualdade que se pretende alcança e que o feriado é parte deste projeto e não apenas um dia de folga, mas, um dia de conscientização, no que faz duras cíticas ao Presidente da ACP. 
Chama atenção para um fato divulgado, isto é, para a ideia de "Curitiba, Cidade das Etnias", no qual as de ascendência europeia tem maior destaque em detrimento de outras, sendo esta mais evidente no que tocam as populações afrodescendentes, reforçando o fato da transformação do feriado em ponto facultativo, aos olhos do Vereador é uma injustiça contra esta população, que teria nesta data o resgate de sua história, lembrando aos presentes que esta população ao contrário de outras que aqui se fizeram presentes, não vieram para o país por vontade própria, mas antes, lhes foi imposta a vinda para cá, bem como, os trabalhos forçados e o regime de violência ao qual foram submetidos, no que o feriado seria um momento de resgate e reflexão sobre esta memória.

Deixa claro seu desapontamento, no sentido que dá a conhecer que houve um movimento dentro da Câmara, para transformar o Feriado em ponto facultativo, ao que parece um esforço da Casa que teve como objetivo dois intentos, primeiro mudar o sentido da data de feriado para ponto facultativo, para descaracterizar a ação proposta pela ACP de inconstitucionalidade da mesmo e em segundo lugar apaziguar a mesma dando a ela o que necessitava a retirada do feriado, pelo menos em termos, uma vez que manteria a data criando, o que seria um meio termo entre os desejos da Associação e o Movimento Negro, no que parece que tanto a mudança quanto o resultado da votação trouxeram, mais descontentamento e tensão a casa, no que na visão do Vereador acabou por evidenciar, algumas questões como uma visão escravocrata da ACP, bem como, a força do poder econômico desta em relação aos demais membros, que segundo este, buscaram mesmo evitar a todo custo demonstrar um voto de consenso sobre o tema, no intuito de evitar um confronto direto com a instituição.

Desta feita, ao continuar sua fala Pop, aponta para o racimo existente na cidade e como este tem um caráter insidioso, na medida em e que este se faz presente nas entrelinhas das relações sociais e mesmo institucionais, principalmente quando os interesses da população negra se chocam contra os interesses econômicos da elite econômica representada pela ACP, que segundo este são análogos àqueles que fizeram da escravidão um meio de lucro, sobrepondo seus interesses ao da população, fato evidenciado pelos $87 \%$ da população que apoiavam a adoção da data, e que viram seus interesses solapados pela manobra ocorrida na Casa, no que Pop solicita união da mesma para enfrentar esta questão, e ainda, para que não seja desmoralizada frente a sociedade.

Pop percebe destaca que a lei é um retrocesso diante da agenda progressista que hora vem se fazendo, bem como, um trabalho de ocultamento da população negra e sua memória.

O Vereador completa sua fala, tratando da memória e a história dos escravizados e seu percurso até sua chegada ao Brasil, e termina lamentando o resultado da votação, sentenciando; "Dezessete votos favoráveis e cinco contra! Vou me retirar daqui porque estou emocionado e quero falar pela razão e não pela emoção."

Posteriormente, as reflexões e considerações feitas pelo Vereador Mestre Pop, o Vereador 
Paulo Salamuni, argumenta e faz um breve resumo sobre a tramitação do projeto do feriado na Casa, esclarecendo que a data mesmo aprovada teve dificuldades em ser sancionada,pelo Prefeito Ducci, que à época apoiou o andamento do mesmo, mas, na hora de efetivá-lo deixou para a próxima administração, que embora não seja citada na ocasião, isentou-se, ficando deste modo, a sansão a cargo da Presidência da Câmara que na ocasião era exercida pelo próprio Salamuni.

Continuando sua reflexão, Salamuni de certa maneira, procura esclarecer que a aprovação do feriado tem haver com um certo "ajustes de contas" com o passado da Casa onde muitas leis que que visavam controlar, constranger e punir as condutas e mesmo a população negra da cidade. Deste modo, votar uma lei em favor deste grupo, seria desta forma uma maneira de espiar e/ou até colocar em perspectiva o modo como os representantes da Câmara e certo momento agiram em relação a população negra, fazendo um paralelo ao tratamento reservado aos imigrantes que vieram mais tarde compor e formar a população de Curitiba, tendo em vista que estes passaram por aflições e dificuldades na chegada e adaptação ao novo país, mas, nada comparado aos sofrimentos vividos pela população negra durante a escravidão, onde este justifica e exemplifica suas afirmações.

Posição que é reforçada, pelo Vereador Valdemir Soares, ao indicar o movimento da ACP, ao longo e nos bastidores do mundo político da Câmara no intuito de convencer e mesmo pressionar os membros da Câmara para que o feriado não fosse aprovado.

Contudo, aprovação do feriado, não significou a sua efetivação, pois, embora, a ocasião tenha espelhado uma grande valor simbólico e mesmo, um elemento de empoderamento da população negra, a vitória provou-se provisória, uma vez que, a ACP recusou-se a aceitar a derrota e levou a questão para o âmbito judiciário, o que acarretou a interdição, naquele momento temporária, entretanto danosa. Esta situação é alvo de uma última reflexão sobre o tema por parte do Vereador Pedro Paulo que resume a situação sentenciando:

Primeiro a promulgação de uma vontade da maioria dos representantes do povo declarando feriado o Dia da Consciência Negra, um dia de luta e de luto em memória daqueles que construíram o país e que sofreram por isso. Mas registrar a minha concordância em que a Mesa envide todos os esforços no sentido de derrubar essa liminar. É uma decisão temporária que pode ser sim, é possível, não é garantia mas é possível, derrubada da mesma forma como foi conseguido pelos seus propositores. O meu apoio a esse esforço da Casa no sentido de derrubar essa liminar e garantir a efetivação da lei aprovada e promulgada por esta Casa.

$\mathrm{Na}$ reunião realizada no dia 06 de novembro, o Vereador Jorge Bernardi em sua fala faz algumas considerações sobre a questão do Feriado do Vinte de Novembro, tendo em vista este ser o único feriado, a ser de fato votado na cidade durante os seus 30 anos de legislatura, já adiantando a possibilidade da interdição do mesmo pela justiça, no que demonstra certa preocupação de que a cidade seja vista como racista pela intransigência no cumprimento do feriado ocasionado pela disputa com a ACP, no que este apresenta sua preocupação. Esta preocupação fica mais evidente quando Vereador observa o que aponta a imprensa sobre o que está ocorrendo em Curitiba, por conta do 
feriado, reforçando que o mesmo nada tem a ver com o fechamento do comércio, e a atitude de promover a interdição do mesmo é antes de tudo, danosa ao turismo, uma vez, que pode transmitir uma imagem equivocada da cidade e que na verdade o comércio teria mais a ganhar que a perder com a adoção do mesmo, argumento que parece denotar certa perplexidade do Vereador frente ao quadro apresentado.

Deste modo, o Vereador Jorge Bernardi impõe uma reflexão sobre a importância simbólica da data em uma cidade, dita majoritariamente branca - Cidade Europeia- gente ao imaginário nacional.

Neste contexto, projeto curioso é o proposto em Projeto de Lei Ordinária de 12 de Novembro de 2013, de iniciativa do Vereador Professor Galdino (João Galdino de Souza) ${ }^{41}$, onde este por meio de seu projeto "Institui o dia 20 de janeiro como feriado municipal e "Dia da Consciência Indígena" no calendário oficial do Município de Curitiba.", que aponta para a diversificação na que toca o princípio da inclusão fato este importante, contudo este parece relativizar a questão do Feriado da Consciência Negra.

No entanto, o projeto acabou por receber parecer contrário e portanto, sendo arquivado.

Em 13 de Novembro de 2013, ao final da reunião realizada nesta data o Vereador Pedro Paulo desta que existe uma agenda de atividades voltadas para o dia da Consciência Negra, inclusive com a divulgação por meio do site da Prefeitura, demonstrando a disposição da Casa em manter as comemorações relativas a esta data, mesmo não havendo o feriado como estava programado, uma vez que a ACP, logrou êxito na interdição do mesmo, por conta liminar do STJ-Pr, que tratava tinha como escopo a inconstitucionalidade da data.

Neste sentido, Paulo Salamuni, salienta que a Câmara por meio de seus representantes legais, com o apoio da Vice-prefeita e Ministério Publico, estão esforçando-se para derrubada da liminar que culminou com a derrubada do feriado em questão, alegando a constitucionalidade da decisão tomada pelos Vereadores.

Na sessão de 18 de Novembro de 2013, antes do início efetivo dos trabalhos da Casa, a Vereadora Professora Josete, faz uso da palavra para chamar atenção aos eventos e debates relativos ao Vinte de Novembro, indicando debates e discussões que terão como os debates relativos as relações étnico raciais tendo em conta a presença de Representantes do Movimento Negro, tanto na data em questão quanto no dia 22 do mesmo mês, tratando de temas com saúde, questões de gênero, enfrentamento do racismo,etc..

41João Galdino de Souza (Professor Galdino), nasceu em 08/08/1962, natural de São Carlos do Ivaí. Professor e político filiado ao PSDB. Formado em História e Estudos Sociais. Elegeu-se Vereador para o primeiro mandato em 2008. Tomou posse em 2009, sendo reeleito em 2013. Em 15/12/2016, o Vereador Professor foi afastado do cargo de Vereador por suspeita de agressão à Vereadora Carla Pimentel. 
Na ocasião o Vereador Paulo Salamuni para o fato de que alunos do sétimo ano do "Colégio Jesuíta Nossa Senhora Medianeira" que vieram a presença deste para entregar um abaixo -assinado formulado por estes em favor da efetivação do feriado da qual fez a leitura, no que aproveitou a ocasião para dar ciência da situação do andamento das ações da Câmara em favor da efetivação do feriado.

Outro elemento evidente na fala de Paulo Salamuni faz uma defesa enfática em prol da independência e autonomia do Estado frente as demandas de interesses particulares, onde segundo este, deve haver prevalência do primeiro, dado que este foi eleito pela população para representar seus interesse em detrimento de quaisquer demandas particulares, no que o feriado da Consciência Negra, estaria portante respaldado na vontade popula. Aponta, para a sombra de uma ação plutocrática, que visa por meio de seu poder financeiro impor seus interesses sobre os demais, denotando uma luta encarniçada entre os interesses públicos e privados.

O Vereador Sabino Picolo chama atenção pela "coragem e pela determinação com relação a lei aprovada nesta Casa do Dia da Consciência Negra.”, aponta o respeito da Casa com relação a determinação do STJ-Pr no que tange a liminar que interditou o feriado, entretanto, salienta que, "Respeitando a justiça, mas nós Vereadores de fato temos que fazer valer aquilo que aprovamos aqui. Esta Casa é uma casa de leis e as leis que são aprovadas aqui têm que ser respeitadas.”, denotando uma clara oposição ao que fora imposto pela justiça, na medida em que questiona a legitimidade da Câmara, isto é, que a grosso modo, coloca em cheque certos valores democrático que estão em jogo no debate que hora se evidencia.

Salamuni, reforça sua posição tendo em vista o apontado por Sabino Pícolo, insistindo na legalidade da lei que antes de mais nada, ao contrário do que disse em outra ocasião, foi objeto de intenso debate entre os parlamentares, inclusive no que toca a constitucionalidade do mesmo apontando que esta questão fora esmiuçada.

O Vereador Pedro Paulo, endossa o argumento de Salamuni ao chamar atenção para um artigo pulicado no Jornal Gazeta do Povo, de autoria de Rogério Galindo onde este salienta que, "Por preço na democracia é algo perigoso."

Logicamente, o Vereador alude ao fato desta discussão ser pautada por um viés puramente econômico em que o social e o político acabam subsumidos por esta dimensão, que sob muitos aspectos colocam em segundo plano avanços sociais importantes, como uma agenda que tenha como pauta a reparação histórica das injustiças sofridas pela população negra, como se evidencia nas falas proferidas.

Novamente, Salamuni chama atenção para a independência da Casa, frente aos grupos da sociedade e que legisla para ela, no que reforça mais uma vez a posição da Câmara no assunto sentenciando que: 
Agradeço e registro ainda o seguinte, no final a Casa ganha. Ganha porque ela não está subjugada ou submetida a qualquer espécie de poder paralelo na cidade de Curitiba. [...] Não precisamos pedir licença a ninguém para nada. Isso ganha a Casa. As pessoas têm que observar. Não é o nosso discurso que muda a conduta, não é discurso do falso moralismo, episódico, momentâneo e pequeno, que vai fazer a Casa maior ou menor. São atitudes macro. Atitudes nossas em defesa de uma lei que foi votada aqui é para dizer que não estamos brincando aqui, sabemos o que estamos fazendo. Podem não concordar, esse é um direito, mas não podem descumprir. A Casa ganha a médio e longo prazo com esse tipo de independência. Isso é crédito, é uma forma independente de legislar, respeitando assim.

A Vereadora Professora Josete, retorna à sua fala ao apontando para elementos relevantes sobre o feriado em discussão retomando um debate sobre questões referentes ao dia 13 de Maio, em que argumenta de modo pungente que a libertação objeto comemoração desta data, não implicou a este grupo um status de cidadão e reforça o caráter crítico e de inflexão da comemoração e portanto, da urgência do mesmo como uma forma de resgate da cidadania deste grupo excluído da população.

No que a Vereadora recupera um debate importante sobre o Vinte de Novembro, já apontado no início deste trabalho, como aponta para uma discussão já realizada por um dos líderes do Movimento Negro, o Senador Abdias Nascimento em 13 de Maio de 1997, onde o mesmo aponta a data como uma mentira cívica, denunciando as mesmas questões abordadas de maneira mais sucinta pela parlamentar.

Na mesma linha, o Vereador Mestre Pop, ressalta que aquilo que a Vereadora Josete já havia apontado, ao afirmar que a liberdade e/ou a libertação,nada mais foi que uma outra forma de negligenciar a população negra, que agora livre não tinha para onde ir, nem o que comer, e que deste modo, esta acabou por significar um processo de exclusão ainda maior onde muitas vezes este grupo liberto, acabava por permanecer aonde estava apenas, por "um prato de comida".

A própria Vereadora, chama atenção para este ponto reforçando que havia inclusive vivenciado esta situação em casa durante sua infância, ou seja, Josete acaba por demonstrar o descompasso entre a realidade e o discurso de liberdade e igualdade aponto-os como um libelo.

Fazendo um aparte sobre o exemplo dado pela Vereadora, o Vereador Pop, expõe os debates enfrentados por ele em se tratando do tema, inclusive citando exemplos pessoais sobre discriminações vividas por ele.

Desta forma, o Vereador apontou a existência do racismo na sociedade que possui em si um elemento léxico que define coisas e lugares para brancos e negros,ou seja, um homem negro de terno em um estacionamento só pode ser o segurança, no que fica evidente o lugar destes indivíduos a subalternidade, e talvez o apontamento mais comovente do desejo por respeito e tratamento igualitário, um dos elementos presentes na disputa pelo feriado.

Neste sentido, após a fala doo Vereador Pedro Paulo, que faz um aparte sobre a questão do feriado, apontando seu apoio ao mesmo informa que durante a semana o Vereador Paulo Salamuni deve ir à Brasília representar em favor do feriado, o Vereador Mestre Pop, retoma as suas 
considerações para reforçar que ação impetrada pela ACP tem um caráter racista que depõe contra a mesma, na mediada em que esta aponta prejuízo econômico como justificativa para opor-se a data, afirmando que este atrapalha o consumo e o fluxo do comércio, no entanto, o Pop aponta que existem outros feriados igualmente "improdutivos" do ponto de vista financeiro e que entretanto a Associação não se insurge contra estes, mas, apenas contra o Vinte de Novembro, ato que segundo aponta o mesmo acaba por evidenciar uma atitude preconceituosa da mesma.

O questionamento do Vereador é acompanhado por Pedro Paulo, que aponta a legitimidade da ACP, no que toca ao questionamento da data, mas, não a respeita devido ao valor simbólico que ela representa tanto para a comunidade negra quanto para a população da cidade, no argumenta o alegado prejuízo econômico apontado pela ACP.

Isto é, a questão de consumir em determinada data ou não, o aludido prejuízo ou não deveriam ser questionados e são passíveis de uma crítica, uma vez, que ao apresentar os valores, a ACP, não apresentou a fonte dos números, apenas, lançou os valores e tão somente.

Por fim, os Vereadores Pedro Paulo e Valdemir, salientaram a questão do ponto facultativo praticado na Câmara por conta do feriado, apontando, que durante a data mesmo sem o expediente formal, se farão presentes nas atividades relativas aos eventos realizados nas comunidades, denotando o caráter e a importância do feriado.

Porém em 20 de Novembro 2013, durante o ponto facultativo estabelecido pela Câmara está em andamento a ACP solta um informativo por meio de suas redes, intitulado "Nota de esclarecimento - Dia da Consciência negra", no qual busca de modo sucinto, reforçar seus argumentos e buscar imiscuir-se da aura de racista atribuída pelos diversos discursos realizados pelos vereadores na Câmara, bem como, pelos representantes dos diversos segmentos do Movimento Negro que manifestam-se em diversos atos pela cidade frente a interdição do feriado pela instituição.

Neste período a Câmara Municipal de Curitiba, passa a discutir um novo projeto relativo a a população negra da cidade, o projeto que alude ao Feriado do 20 de Novembro é o de Emenda Orçamentária Aditiva, proposto em 02 de Dezembro de 2013, pelo Vereador Jorge Bernardi, que versa sobre a Festa da Lavação das Escadarias da Igreja do Rosário dos Pretos de São Benedito, que como apontado anteriormente tem vínculo direto com o Dia da Consciência Negra, no qual dispõese a tratar da inserção de recursos relativos à atividades da Secretária de Turismo a fim de dar maior suporte ao evento, apontando para a importância turística e cultural do mesmo, uma vez que, este adiciona incremento ao comércio que se faz presente junto ao evento, fazendo alusão ainda, a atração do turismo produzida pelo mesmo, apontando a necessidade da disponibilização de material de propaganda e suporte ao evento.

Em 09/12/2013, o site da ACP, faz a divulgação de um novo evento, sobre o título "Fundador da ACP é lembrado em dia de combate à violência contra as mulheres”, no qual a instituição aponta 
as virtudes éticas e morais da mesma, evento que contou com várias autoridades políticas.

O que se observa aí é que embora, a ACP é que o tema do Dia da Consciência Negra é tangenciado, isto é, é mencionado mas, não é discutido em um evento que como ponto central o enfrentamento a violência, e neste caso violência contra mulher.

No mesmo mês em sua revista de Dez/2013, o seu presidente Edson Ramon, em editorial aponta "Atuação marcante e dinâmica" ao tratar do desenvolvimento e crescimento das ações da instituição no que aponta:

Mediante a dinamização da área de novos negócios, produtos e serviços destinados a garantir benefícios e vantagens aos associados, a ACP passou a preencher algumas lacunas em sua operação e atendimento de necessidades do mercado e expansão do ambiente de negócios. Alargando sua presença no interior do Estado, por meio de convênios de cooperação com associações comerciais e outras entidades empresariais de vários municípios, a ACP implantou escritórios nas importantes regiões econômicas de Maringá e Londrina, com o objetivo de estar mais próxima das necessidades dos empresários.

No aspecto institucional, o exercício foi marcado por uma série de eventos que revigoraram a interação da entidade com governantes federais, estaduais e municipais, além de personalidades do Judiciário e do Legislativo. O diálogo aberto e respeitoso, sem abrir mão do direito à divergência, trouxe esclarecimentos necessários para a afirmação das posições da Casa na defesa da livre iniciativa e liberdade de expressão, entre outros valores éticos e morais.

A noticia novamente se aferra aos preceitos ético e morais da instituição, e aponta que esta defende a liberdade de expressão e o bom diálogo com as autoridades publicas, no entanto, faz esta fala anunciando a sua expansão com escritórios para a região, no entanto, parece importante salientar que as cidades de Maringá e Londrina são dois dos municípios que optaram pela adoção do feriado do 20 de Novembro e o fizeram, em um contexto endo o de Curitiba havia sido barrado, coincidência ou não após criação destes dois escritórios na região o questionamento da data tornou-se mais forte nestes e posteriormente ao longo do anos foram barrados por ações de escritórios da ACP, nas suas regiões.

Sobre a questão do 20 de Novembro a mesma publicação de jornalistico sobre "Dia da Consciência Negra" no reitera elementos já tratados sobre a posição da instituição sobre a questão do feriado, a decisão do judiciário, o aludido prejuízo econômico a cidade, bem como, o respeito a história de Zumbi e a população negra, contudo, ao resumir o ponto de vista da instituição o Presidente Edson Ramon é enfático ao afirmar que:

[...] acima de tudo com o objetivo de "advertir autoridades e sociedade para as perdas econômicas com o fechamento das portas da indústria, comércio e serviços em mais um dia, especialmente na fase de abertura da temporada de final de ano". Resumindo a posição conjunta das entidades, Ramon enfatizou que "não é justo que um dos setores responsáveis pela geração de milhares de empregos, recolhimento de tributos e geração de renda se veja impedido, mesmo sob a alegação do resgate histórico, de cumprir sua missão".

Há aqui uma novidade, no sentido que estes alegam que o feriado é um empecilho as atividades financeiras da instituição e seus associados, bem como, enfraquece as suas afirmações de respeito e compreensão da cultura negra ao afirmar que a geração de lucros não pode se pautar pela 
“alegação de resgate histórico", fato que revela um novo olhar sobre as ações do grupo, na medida em que vê como algo irrelevante um objeto de disputa simbólica para a população negra, ou ao menos expõe de modo mais claro a real visão da instituição quanto ao tema em si.

Em outra nota do exemplar, repete de modo, mais sistematizado notícia que tratava da decisão que embargou ao feriado, sob o título G TRIBUNAL - JUDICIÁRIO DE JUSTIÇA DO ESTADO DO PARANÁ 19. FERIADO O ÓRGÃO ESPECIAL DO TJPR, onde retomam,como uma forma de demarcar a situação, batendo sobre os pontos já tratados.

\section{ENTRE DISCURSOS E RETROCESSOS}

Tendo em vista os elementos apontados pela ACP no ano anterior, o Vereador Chicharel, parece estar em sintonia com as ideias da instituição, na medida em que apresenta um projeto que caminha no mesmo sentido desta.

O Projeto de Lei Ordinária, apresentado em 14 de Março de 2014, pelo Vereador Chicarelli (José Carlos Chicarelli) $^{42}$, na qual pretende aludir sobre a capacidade ou poder da Municipalidade em arbitras feriados.

Neste sentido, tece críticas ao feriado da Consciência Negra, que segundo este além de estar em inconformidade com a Lei Federal, ainda poderia acarretar sério prejuízo financeiro a cidade, em oposição ao que relata anteriormente.

No sentido oposto, o Vereador Jorge Bernardi, aponta que o evento da Lavação da Escadaria da Igreja do Rosário, atividade esta estreitamente ligada ao 20 de Novembro, necessitava mais investimento devido ao potencial econômico gerado por esta atividade, o que em muitos aspectos desmente a justificativa de cunho econômico apontada pelo Vereador Chicarelli.

É interessante notar que a grita da ACP, criticada pelo Vereador Jorge Bernardi, aponta para um fato estranho na medida em que a parada do feriado, afetaria as compras de fim de ano, mas, precisamente as compras de Natal e levaria a uma paralização de "quatro dias em uma semana" ao que não encontra amparo lógico, já que o Natal ocorreria à pelo menos trinta e cinco dias após a mesma e que este acarretaria um fechamento de quatro dias, para uma parada de um dia?!

Contudo em 19 de Março de 2014, o Vereador Chicarelli retorna a tribuna da Câmara para retomar sua posição, inclusive se utilizando de argumentos semelhantes aos da ACP, bem como outros, ásperos para tratar do tema.

42 José Carlos Chicarelli ( Vereador Chicarelli), nascido em 20/09/1962, natural de Engenheiro Beltrão, PR1. Elegeu-se para um único mandato em 2012, tomando posse em 2013, não sendo reeleito em 2016. No entanto, o atual Prefeito Rafael Greca, nomeou Chicarelli, do PSDC, para a função de Gestor Público Municipal, sigla EAG, símbolo C-3, ligado à Secretaria de Governo, prestando serviços na Secretaria Municipal do Meio Ambiente, com rendimento mensal de R\$ 9,9 mil, conforme aponta o Jornal Gazeta do Povo. 
Nesta sessão presidida pelo Vereador Tito Zeglin, é concedida a palavra ao Vereador Chicarelli, usa do expediente para, a princípio, tratar dos feriados da Copa, que foi objeto de discussão em sessões anteriores, e questionados por parte ACP que alegava prejuízos econômicos por conta destas, entretanto, como se observa, este não se restringe a um debate sobre a questão dos dias de jogo e logo dirige sua fala contra o feriado da Consciência Negra

O que se observa, na fala um tom irascível quase de desdém, quando se coloca em relação as efemérides, no que "ao dia em homenagem ao sei lá oque", detalhe que evoca o dia da Consciência Negra, sempre lembrado como um dia de homenagem a população negra, elemento que se faz presente nas exposições feitas por vários Vereadores ao longo dos debates até aqui apresentados, por outro lado relativiza a importância da data ao citar o "Dia da Consciência Indígena" proposto pelo Vereador Galdino, e ao comparar a trajetória dos imigrantes italianos que vieram ao Brasil, sugerindo que se fosse pesar pelas dificuldades passadas por aqui estes "deveriam ser homenageados com uma semana de feriado, se fosse o caso", o que demonstra a agressividade do representante a data que representa a população negra, no que finaliza a sua fala afirmando que "nós, deveríamos estar aqui tentando estimular a questão dos trabalhadores para que eles estimulassem os patrões a abrir os comércios, não fechar.", no que, parece ser uma inversão de termos ao dizer os Vereadores ou a Câmara deveriam estar "estimulando os funcionários a estimular o patrão"?!

No mês seguinte, enquanto se desenvolve o debate em torno do tema, conforme registar o site da instituição o Presidente da ACP, é entrevistado em programa da Rede Bandeirantes de Televisão, programa realizado no dia 10 de maio de 2014, que foi reproduzido em 13/05/2014, nos meios de comunicação institucional da associação, com a chamada "Edson Ramon fala sobre a ACP em programa televisivo", onde de modo resumido o seu presidente falou, entre outras coisas sobre "Quanto às recentes vitórias da entidade, falou da luta contra a instituição de feriados em jogos da Copa em Curitiba e no dia da Consciência Negra."

O mês de agosto de 2014 é marcado pelo término da gestão do Presidente Edson José Ramon da ACP, sendo sucedido pelo empresário Antônio Miguel Espolador Neto, em discurso reproduzido em 12/08/2014, intitulado “Leia a íntegra do discurso do ex-presidente Edson José Ramon' este faz sua despedida do cargo, fazendo um breve balanço de sua gestão e mesmo das conquistas realizadas durante a mesma. Em sua fala destaca-se ainda, a boa entrada da associação dentro das estruturas institucionais do aparelho do Estado, bem como o fato desta apresentar-se como uma liderança dentro de um conjunto de associações e fundações ligadas a indústria e ao comércio, assim como, as relações estabelecidas com a estrutura jurídica do Estado do Paraná, que se firmou durante o processo de luta para a criação do Tribunal Regional Federal da 4a Região, no Paraná, e finalmente a interdição do feriado da Consciência Negra.

Neste contexto, apesar da derrota imposta pela ACP a administração pública, no caso, a 
vereança da cidade, o debate na Câmara continua a se fazer presente. Em 17 de Outubro de 2014, o Vereador Jorge Bernardi, propõe Requerimento de Realização de seminário /simpósio, em que "Solicita a realização de Seminário na data de 27 de novembro de 2014. Tema: "Dia da Consciência Negra: Políticas afirmativas para promoção da igualdade racial"., em que procura agregar de mesmo modo os agentes da sociedade civil organizada e representantes de outras entidades, representadas pela "Secretaria Municipal de Educação, Fas, Ministério Público/PR, OAB/PR, TJ/PR, Docentes do Centro Universitário Uninter, UFPR, PUC/PR, e comunidade civil organizada.” a fim de debater sobre o Feriado do 20 de Novembro.

Posteriormente, na sessão de 10 de Novembro de 2014 o debate acerca da data é retomada pelo Vereador Paulo Salamuni.

Na sessão presidida pelo Vereador Paulo Salamuni, se realiza um debate intenso sobre a necessidade de fixar leis sobre o tempo de permanência dos cidadãos em filas em serviços públicos tais como bancos e cartórios entre outros, se discute ainda, a competência e constitucionalidade da Casa ao propor e aprovar estes temas, o Vereador Tico Kuzma, faz uma breve reflexão, utilizando como expediente a jurisprudência criada por um Juiz do Estado de Mato Grosso sobre a possibilidade do Município legislar sobre si.

No que aponta nesta jurisprudência elementos que justificam a Constitucionalidade, bem como, a legitimidade do Município criar leis específica para si, o que ocorreu no caso do Dia da Consciência Negra, elementos estes que poderiam servir de subsídio para questionamento sobre a liminar impetrada pela ACP, entre outras demandas da Câmara.

Já na sessão de 17 de Novembro de 2014 o tema reaparece na fala da Vereadora Noêmia Rocha. Nesta ocasião ocorre um debate intenso a respeito da criação de quotas ou ônibus especiais para mulheres como forma de melhorar o acesso destas ao transporte publico, assim como um meio para evitar abusos e violências por elas vivenciadas dentro deste tipo de transporte, no que a Vereadora Noêmia Rocha, chama atenção para lei tendo como exemplo a população negra ao afirmar que:

[...] Mas, nós temos o princípio da igualdade material, que trata os desiguais na medida da sua desigualdade, como as cotas de negros nas faculdades federais. (M) Então, o princípio da interpretação de direito: os ônibus vão segregar para proteger, se eles vão segregar para proteger um grupo diferente que precisa de tratamento desigual. Isso está dentro da Constituição, no Artigo 5o, no Parágrafo $2^{\circ}$ : princípio da igualdade. Esse princípio permite tratar de forma desigual para atingir a igualdade. Eu acho que essas mulheres, eu não ando de ônibus, andei há muito tempo, mas eu tive um assédio quando andava de ônibus, e é a pior coisa para uma mulher, essas mulheres precisam de respeito. E eu não tenho dificuldade nenhuma de responder a essas mulheres que andam de ônibus diariamente, trabalhadoras, que precisam de respeito. E isso as torna em uma forma como a cota de negros, elas merecem esse respeito. Voto favorável com muita tranquilidade, entendendo que essa lei não vai resolver. Mas se ameniza o sofrimento dessas mulheres [...]

A fala é interessante porque aponta para certos elementos que podem ser transpostos para o debate sobre o feriado, na medida, em que este se oferece como política afirmativa e espaço de 
afirmação, no que toca a questão da equidade, isto é, de prover meios de equivalência entre desiguais, ou seja, tratar de forma desigual os desiguais, no que a data promove um espaço para a discussão sobre o que é igualdade. Por outro lado, equilibra e/ou contrapõe a representatividade hegemônica do imaginário de sociedade branca europeia com a promoção de um espaço efetivo de afirmação para a população negra, bem como, coloca em perspectiva certos aspectos relativos as politicas afirmativa, no sentido de que evidencia que os seus benefícios transcendem os grupos para os quais estas foram pensados, criando subsídios para a implementação de direitos às outras categorias e/ou minorias sociais, que muitas vezes se acham à margem das políticas sócias, como no caso das mulheres por exemplo.

Na sessão de 18 de Novembro de 2014 o Presidente da Câmara Vereador Paulo Salamuni, faz um breve relato trazendo ao conhecimento da Casa, um breve panorama de como se encontra a questão do feriado do 20 de Novembro que está sob judice, ao mesmo tempo que faz um desagravo, quanto a esta condição, apontando que existe um agravo junto TJ-Pr, o que por sua vez, continua impedindo a realização do feriado, questão que tem como base a alegação por parte da ACP de inconstitucionalidade, fato que não é entendimento pacífico por parte deste e visto ainda como uma usurpação do poder. Contudo, aponta que na Casa a data será ponto facultativo de modo, a fazer valer pelo para estes o feriado, de tal sorte que salienta o caráter simbólico deste. Realizada esta fala, os trabalhos seguem adiante sem nenhum questionamento ou posição dos demais presentes no que toca o tema, partindo logo para assuntos outros, sem relação com o tema do feriado.

Um dia antes do que seria o feriado, 19 de Novembro de 2014, o vereador Paulo Salamuni, usa a palavra para fazer a defesa da data, e em certa medida apontar que embora, a lei esteja sob judice esta deveria ser cumprida enquanto não se decide sobre sua legalidade ou não.

Neste sentido, além de reforçar pontos já afirmados em outras ocasiões, sobre a importância do feriado e mesmo sobre a questão do ponto facultativo na Câmara, parece dar uma resposta ao Vereador Chicarelli que apontou os "sofrimentos" dos italianos chegados ao Brasil, no qual este deixou subtendido que a História da população negra e o seu sofrimento não seriam condições suficientes para justificar um feriado, já que em suas palavras "estes sofreram talvez tantos quanto os negros trazidos em porões de navios", no que Salamuni em sua fala socorre-se de sua própria trajetória de filho de imigrantes, bem como, do registro histórico da Câmara, para pôr em perspectiva este discurso, ainda que a referência não seja direta.

Salamuni o faz, apontando que se houve discriminação contra os imigrantes esta não chegou a se verificar por leis tão atrozes quanto uma lei aprovada na Casa no Século XIX, que permitia marcar a ferro um escravizado fugitivo, fato que denota um abismo de diferenças entre o tratamento dado ao colono europeu e trabalhador escravizado de origem africana.

Nesta mesma linha, o Vereador Mestre Pop, realiza um desagravo, ao criticar o epíteto de 
“Capital Social”, na mediada em que a Capital é mais social para alguns do que para outros.

E completa a sua observação retornando a crítica em relação a ACP, que teria utilizado de seu poder econômico para impor seus interesses sobre a sociedade como um todo, deste modo, atacando o direito da população negra, com afirmações infundadas como, a questão do prejuízo ao comercio, afirmação refutada pelo vereador, tendo em conta ou como exemplo a cidade de São Paulo, onde as mesmas justificativas foram apontadas para tentar barrar o feriado, sendo contudo, refutada com os resultados econômicos contabilizados pós feriado que apontaram para um crescimento das vendas no comércio.

Durante a sessão Salamuni aponta a presença dos representantes do Movimento Negro Saul Durval da Silva, ex-Presidente do Conselho Municipal de Política Étnico Racial, e de Denis Denilton, Presidente do Conselho Municipal da Igualdade Étnico-racial, que farão uma fala em um contexto interessante durante o evento.

O contexto se dá pela fala de outros convidados para Tribuna Livre, espaço reservado à membros e representantes de certa importância na sociedade para que possam fazer apontamentos, trazer informações, reivindicações, etc; aos membros da Câmara. Neste caso, os convidados foram os representantes da Legião da Boa Vontade (LBV) Lucymara de Andrade, Dra. Raquel Costa, Assistente Inter-religiosa de Educação. Sr. Vinícius, Assessor de Comunicação de Marketing da LBV, Sra. Regina Santos e Sra. Geni Batista, do Movimento dos Focolares, e que vieram a Casa tratar sobre o Dia de Oração e Ação pela Criança, projeto de Lei n ${ }^{\circ} 4.348$, a apresentação do tema ficou a cargo da Sra. Lucymara, que foi na ocasião apresentado pelo Vereador Geovane Fernandes, responsável pelo convite.

Ao tratar do tema relativo a data, esta afirmou que se tratava de uma ação de cunho ecumênico, na medida, em que comunga pessoas, grupos e representantes dos mais variados grupos religiosos, que principalmente nesta data, reúnem-se para fazer atividades voltadas para a sociedade tendo como publico alvo as crianças.

O interessante é notar que data proposta para como Dia Mundial de Oração em Ação pelas Crianças é o 20 de Novembro, data do Feriado que se acha em disputa e é alvo de questionamento de alguns vereadores como é o caso do Vereador Chicarelli, contudo, como ela esclarece, "[...]O Dia Mundial de Ação e Oração pela Criança vai acontecer em Curitiba, no dia 22 de novembro, das $13 \mathrm{~h}$ às 17h em dois locais: um na Rua da Cidadania da regional Boqueirão, lá no Terminal do Carmo [...]", do que ela busca salientar a importância da data, apontando para o cuidado com as crianças e adolescentes, carentes e/ou que se acham em situação de risco, no que ela termina sua exposição dizendo que "O sangue que corre aqui dentro é vermelho de todo mundo, mas os nossos gens estão misturados e são todos realmente irmãos.”. Importante é indicar, que isto pareceu indicar a tentativa de dirigir a data em questão para um outro lugar, na medida em que apresenta outros interesses sobre 
um ponto em disputa, que tem como marco central o dia 20 de Novembro, bem como, a finalização inadequada, que tende para o discurso da "Democracia Racial", que embora não fosse intencional, no quadro geral denotou uma tentativa do grupo de apropriação data, que gerou o contexto no qual emergem as falas de Saul Dorval e Denis Denilton.

Saul é o primeiro a falar, no início de sua explanação retoma a importância social da comemoração para todo o conjunto da sociedade não importando a sua etnia, por conta do espaço para reflexão e reavaliação da mesma que ele propicia, no que toca os males relativos ao processo da escravidão e a herança de desigualdade social e marginalidade legada aos descendentes dos trabalhadores africanos escravizados no processo de construção do país e pós-abolição, no que assevera:

[...] A escravidão no Brasil foi a pior escravidão do mundo, em todas as épocas. Muito mais que na Grécia antiga, escravizada por Roma. Amanhã é o Dia da Consciência, quando temos que voltar ao passado e refletir. Mais do que isso, quero lembrar a esta Casa de Leis que o processo do feriado está no Supremo Tribunal Federal, o qual nós recorremos e estamos esperando a decisão do Ministro Gilmar Mendes, e nós esperamos que seja favorável. Eu quero lembrar que o Artigo 215, da Constituição Brasileira possibilita a criação de feriado. O que a parte contrária disse, em Curitiba, é que se baseia numa lei federal. E, se baseando numa lei federal, nós vamos lembrar aqui a hierarquia das leis. Nenhuma norma jurídica em forma de lei é maior ou superior a uma Constituição. Então, o Artigo 215 estabelece o feriado. E esta Casa de Leis, junto com a população de Curitiba, aprovou o feriado. Então, há arbitrariedade da parte contrária que estabelece alguns assuntos de não relevância, como colocar o capital financeiro em cima do ser humano. A causa, não há dinheiro que pague, no mundo, a questão de uma consciência de uma escravidão ou de uma mazela humana. E, para terminar, quero deixar uma frase do Pastor Martin Luther King, também formado em Direito: "A raça é uma só, a raça é a humana".

Deste modo, a sua fala vai de encontro a defesa da legalidade do feriado e de reafirmar a data como o Dia da Consciência Negra, inclusive do ponto de vista constitucional, onde de modo sutil rebate a ideia de outro sentido para a mesma que não o posto.

Denilton Laurindo (Denis Denilton) é mais incisivo quanto a definição e demarcação dos interesse da comunidade negra, ao sentenciar que:

A igualdade racial, a igualdade de direitos e a igualdade de deveres, e amanhã sendo esse dia de reflexão, nós aguardamos que todos, Vereadores, Vereadoras aqui presentes, os religiosos, possam levantar suas orações, porque amanhá é dia de pensar o quanto nós somos monstruosos de não permitir que o outro exista. Exista na condição de direito e de dever, porque nós, infelizmente, com os nossos direitos e não deixando com que eles sejam estendidos a grande parte dessa população, permitimos que pessoas morram. Amanhã é o Dia Mundial da Oração, façamos orações por aquelas mães que perderam seus filhos pela negligência pública, que perderam os seus filhos pelas drogas, que perderam os seus filhos, os quais, na grande maioria, são negros, nesta Cidade. Então, nós precisamos, a partir dessa causa, a partir desta Casa, unir-nos para derrotarmos a negligência, para reivindicarmos aqueles direitos que não são estendidos a todos e fazermos com que os deveres sejam cumpridos, na medida em que nessa oração, na medida em que essa mão unida de fato, que não tem cor, que não tem religiosidade, mas que tem humanidade, seja sim o reflexo desta Casa de Leis. Muito obrigado a todos. E, amanhã, viva Zumbi dos Palmares! Viva o povo brasileiro! Viva Curitiba!

Nota-se na fala de Denilton, uma posição clara de afirmação quanto a apropriação da data, na 
medida em que coloca em perspectiva a proposição do Dia Mundial da Oração, ao denotar o abandono a que a população negra se acha relegada, bem como, o fato de a maior vítima da negligência é a população preferencialmente negra, para quem orações não são o bastante, solicitando ação por parte das entidades presente e reafirmando a data comemorativa ligada a Zumbi dos Palmares.

\title{
ACP E O MONÓLOGO MONOCÓRDICO
}

Não obstante as todas as fala já aludidas em relação ao feriado, na Revista do Comercio, publicação da ACP, de Janeiro/ Março de 2015, em uma sessão de perguntas e respostas, surge um adendo sobre o feriado, onde lê-se:

\begin{abstract}
Este ano terá muitos feriados prolongados e isso sempre ocasiona perdas para o comércio. O que fazer? Feriados fazem parte do nosso calendário e não há como modificar o quadro. A ACP tem trabalhado com toda a disposição no sentido de evitar a decretação de feriados cívicos em datas aleatórias, inclusive com a manifestação favorável da Justiça, como aconteceu com os jogos da Copa do Mundo e a Consciência Negra, por exemplo. Quanto aos feriados tradicionais, se o setor produtivo sofre a perda estimada em $\mathrm{R} \$ 150$ milhões por dia paralisado, no entanto, os setores de hotelaria, gastronomia e outros serviços de atendimento aos turistas são beneficiados pelo aporte de recursos trazidos pelos milhares de visitantes que escolhem Curitiba para curtir os feriadões.
\end{abstract}

A sessão ganha relevância porque acaba por corroborar alguns pontos de vistas apresentados pelos Vereadores e representantes do Movimento Negro, sobre o lucro gerado pelo turismo por conta do feriado no que este poderia atenuar o supracitado prejuízo objeto admoestação da ACP, bem como, como o valor do referido numerário que hora é de mais de 160 milhões de reais, e aqui chega a 150, valor este que nunca foi objeto de uma reflexão e mesmo, uma auditoria mais profunda, por parte dos grupos favoráveis à data.

Posteriormente em 03 de Agosto de 2015, o Vereador Jorge Bernardi, faz o Requerimento de Realização de Audiência Pública, onde vem a "Requer à Mesa na forma regimental, a realização de audiência pública na data de 12 de Novembro de 2015. Tema: "DIA DA CONSCIÊNCIA NEGRA", no qual vem a Câmara debater a respeito dos temas relativos ao 20 de Novembro. Evento este que contou com a presença dos representantes Ministério Público - Dra. Mariana Seifert Bazzo; OAB Mesael Caetano dos Santos; Universidade Federal - NEAB (Núcleo de Estudos AFRO-Brasileiros) e Coordenadoria de Direitos Humanos da Prefeitura Municipal de Curitiba.

Não obstante ao debate proposto por Jorge Bernardi, a discussão parece perder fôlego ao longo de 2015, sendo objeto de curtas e tangenciados debates, mesmo quando as situações de racismo e discriminação se enunciam dentro da própria Câmara como se verá mais à frente no texto.

Nas Notas Taquigráficas 18 de Novembro de 2015 a sessão presidida pelo Vereador Ailton 
Araujo (Ailton Cardozo de Araujo) ${ }^{43}$, a única fala em torno da questão do 20 de Novembro é realizada pelo Vereador Tito Zeglin, em sua alocução este faz um convite para o evento religioso da lavação da escadaria da Igreja do Rosário, que ocorrerá no domingo próximo, destacando "[...] que três grandes capitais, Rio de Janeiro, São Paulo e Cuiabá, comemoram o Dia da Consciência Negra na sexta-feira, dia 20. Aqui no Paraná, somente Guarapuava e Londrina comemoram. Curitiba ainda não está tendo esse privilégio.”.

Neste sentido, é perceptível que o tema não encontra eco entre os membros da Casa, na medida em que esta fala passa como algo pontual, um informe sem maiores implicações, sem logo seguido por outras, que tratam de assuntos vários.

Nesta sessão de 23 de Novembro de 2015, pós 20 de Novembro, a questão da data parece ter sido deixada de lado, e questão do Dia da Consciência Negra sequer é debatido, no entanto, questões referentes a população negra, acabam por cruzar as falas dos Vereadores, o primeiro a tropeçar no tema é Chicarelli. O vereador assim como os demais, está em um debate acirrado em torno de questões relativas aos moradores de rua e medidas sociais para combater o problema, no que compara a questão dos sem-teto de Curitiba ao que está ocorrendo em Los Angeles.

Interessante notar a preocupação deste com o problema em um local tão distante e mesmo o detalhe no qual observa que a população de rua lá é em sua maioria negra, no entanto, não estabelece de fato nenhum paralelo com a população de rua local, e não fez nenhuma observação sobre o perfil étnico da mesma na cidade de Curitiba.

A sessão de 25 de Novembro de 2015, é iniciada pela fala do Vereado Zé Maria, tendo em vista o caso de racismo que o envolveu, no qual este teria feito uma injuria racial contra outro membro da Casa, neste caso, o Vereador Mestre Pop.

Interessante é notar que a fala do Vereador segue o roteiro comum observado nestes casos, no qual se pode enumerar assim, primeiro a questão da preocupação e do arrependimento, no qual a pessoa que desfere a injúria diz-se arrependida e triste com o evento; em segundo busca se assegurar a partir do apontamento de presentes de que a questão não teve o objetivo de causar ofensa; terceiro, aponta a pessoa do negro como suscetível e que se ofende com facilidade e por conta disto algo sem muita importância teria causado um problema maior ou que a pessoa por ser de um tipo intransigente acabou vendo "maldade" onde não havia, buscando transpor a atitude racista para o outro, neste caso, a vítima.

Neste sentido, o Vereador Mestre Pop, busca organizar a sua fala no sentido de colocar-se

43 Ailton Cardozo de Araujo (Ailton Araujo),nasceu em 11/05/1942, natural de Campina Grande do Sul, Pr. Sua carreira política se inicia em 1988, ano de seu primeiro mandato, sendo reeleito em 1992, 1996 e 2001. No ano de 03/02/2002 renúncia ao mandato de Vereador, para ocupar a cadeira Deputado Estadual. Posteriormente é reeleito Vereador em 2013 e 2016. 
quanto a ofensa desferida pelo Vereador Zé Maria.

Em sua fala o Vereador defende a sua condição de negro e fala cabalmente contra a agressão por ele sofrida e contra as piadas de cunho racial. Apontando para o fato de que tomaria as atitudes legais cabíveis. Apesar do ocorrido não houve nenhuma manifestação, apoio, contradição por parte dos demais vereadores e a sessão seguiu seu trâmite sem nenhum posicionamento da Casa, sobre a questão, uma situação no mínimo constrangedora.

Nesta sessão fez-se presente os representantes do Conselho Étnico Racial (Comper), os quais tiveram a fala solicitada pelo Vereador Pop, que se colocou dizendo "[...]Sr. Presidente, gostaria que o meu tempo fosse cedido ao representante do Comper, Conselho Étnico Racial, para eles poderem falar. Eles estão esperando desde às 10h30min da manhã. Se o senhor puder suspender a Sessão, eu agradeço." Saber o que foi dito pelos representantes do conselho frente a situação hora evidenciada seria um bom elemento de análise e poderia por a par da questão e observar se estes ou os vereadores se posicionaram em relação a discriminação sofrida por Pop, entretanto, as notas taquigráficas, possuem uma lacuna ao não registrar a fala dos membros do Comper.

\section{DESIDRATANDO O DEBATE}

O tema retorna à pauta em 2016, de forma diluída na medida em que parece ter sofrido desgaste ao longo da jornada, contudo, aparece ainda que tangenciada nos debates que envolvem de alguma forma a população negra da cidade.

Na sessão de 20 de Abril de 2016, o Vereador Mestre Pop, aproveita o pequeno expediente da Câmara, para chamar atenção para o tema do 20 de Novembro, dando ciência de que o Feriado, se acha em trâmite no STF, e apontar para o fato de não poder retornar o tema de modo mais profundo como gostaria em uma discussão no plenário da Câmara, e deixa claro o seu desapontamento.

Após a sua fala o que transparece, é uma possível falta de contexto, clima e/ou mesmo adesão na Casa para tratar de maneira profunda o tema, como a exemplo dos anos anteriores, contexto que se reflete na fala do Vereador Serginho do Posto, que após uma longa fala, sobre a competência da Casa para legislar em um debate que tem como centro a liberação do UBER em Curitiba e apoiandose em questões que tocam a competência relativa a cada instância deliberativa no que toca a criação de leis, aproveita a oportunidade para dar mais detalhes sobre o andamento do processo do 20 de Novembro, bem como para expor sua opinião sobre este.

Na sessão de 7 de novembro, o tema do 20 de Novembro, não foi tangenciada, no entanto, a temática da cultura negra se fez presente, na proposição do Projeto de utilidade publica de proposição do Vereador Serginho do Posto, posto que este pretende a Declaração de Utilidade Pública da Associação Berimbau Rosa, sobre o qual se estabeleceu certa polêmica como expõe a Vereadora Josete. 
A exposição da Vereadora Professora Josete, demonstra bem o ânimo de certo grupo da vereança da Casa, que age de modo preconceituoso em relação a temas que tenham ligação com a negritude, dado que segundo a Vereadora, há um prejulgamento do tema no que este é visto como ligado ao candomblé uma das formas de expressão religiosa da cultura negra, o que denota certa gravidade, já que como aponta a mesma a Câmara é laica, contudo, os vereadores se utilizaram de uma bússola moral religiosa para tensionar o tema, embora, suas falas não estejam registradas o quadro de votação e as possíveis falas de bastidor denunciadas pela representante, apontam para este sentido, no que esta se socorre do Vereador Mestre Pop, para dirimir as dúvidas dos presentes e possivelmente tranquilizar os opositores do tema.

Reforçando a fala da vereadora o Mestre Pop, aponta para o preconceito e o racismo embutido no posicionamento de alguns parlamentares frente ao tema, no qual separa sob muitos aspectos a capoeira de certos aspectos religiosos, ao mesmo tempo que não os nega, e coloca em perspectiva a importância desta como fenômeno cultural nacional, bem como, sua relevância como patrimônio imaterial e expressão cultural que abraca todos os públicos tendo em vista que opção pela prática desta não está ligada a uma expressão religiosa específica de um grupo. Também coloca em perspectiva a questão de que há alguns tipos de expressão social e/ou religiosa que são mais toleráveis que outros ao apontar o caso da maçonaria, no que define a tolerância e a liberdade de expressão como um dos elementos a serem defendidos e preconizados na Casa, embora, esta atitude não seja que sempre prevaleça.

Após a defesa do tema por parte do Vereadores Pop e Josete o tema foi a votação e posteriormente aprovado. Esta situação expõe a dificuldade de se colocar certas questões referente e/ou de interesse da população negra curitibana, principalmente em questões de expressão cultural e de cunho religioso.

Embora, pareça à grosso modo, que a questão do 20 de Novembro pareça superada, como apontou o Jornal Bem Paraná ${ }^{44}$, em jornalistico publicado em 2015, ao afirmar em um artigo intitulado "Feriado da Consciência Negra faz parte do passado", e ao afirmar que a aprovação do mesmo fora apenas, uma jogada política que não surtiu efeito, contudo, ao que parece é que em 2017, a questão do feriado ganha novos contornos, na medida em que sua tramitação passa a ser discutida na esfera estadual, como aponta comunicação encontrada na Revista do Comércio de março/maio de 2017, na sessão “E - ASSEMBLEIA LEGISLATIVA DO PARANÁ” a nota que dá conta que há novo projeto em tramitação para a promulgação do na Assembleia Legislativa do Paraná.

44 http://www.bemparana.com.br/tupan/feriado-da-consciencia-negra-faz-parte-do-passado/ 


\section{CONSIDERAÇÕES FINAIS}

O tema da Consciência Negra ou o Feriado da Consciência Negra evidenciam uma questão que tem em foco o lugar social e político do negro na Cidade de Curitiba. Problema este que tem se apresentado como um elemento de longa duração no que toca o imaginário da Cidade, que sempre buscou ocultar a presença do negro e o seu lugar neste espaço. Mas, que em um contexto de transformação social, modernização, organização da população negra, e da adoção de política afirmativas, não tem mais como conter e invisibilizar as questões e contradições expostas, na tentativa da adoção do feriado.

O que se observa é que os debates em torno do tema, apesar de se desenharem em um período de 16 anos, pelo que foi apurado refletem problemas centenários, que estão longe de serem resolvidos, apenas, pela adoção de uma lei ou decreto, mas, que ao se evidenciarem denotam uma mudança substancial no modo de se enxergar a Cidade e como ela pensa a si mesma, assim como, a necessidades de maior enfrentamento destas questões e pesquisas na área.

As pesquisa, na área se fazem necessárias, pois, dado a importância dos fatos observados nos embates em torno da questão do feriado, que eram quase, senão a maioria, os mesmos, ou seja, há a reprodução do problema de tratar sobre o assunto que em geral envolve entre outros temas o controle sobre a narrativa e/ou uma vontade de verdade sobre a identidade de Curitiba.

Esta dificuldade engessa as discussões e impede a chegada à politicas mais concretas no enfrentamento dos problemas aludidos e mesmo a qualificação e ampliação das politicas já adotadas, de tal sorte, que com este trabalho e possíveis pesquisas que possam se seguir, espera-se ter ajudado a lançar mais luzes, sobre a questão, que valem ressaltar, que mais do que um feriado, aludem ao lugar ou ainda, ao não lugar ocupado pela população negra na sociedade curitibana.

\section{REFERÊNCIAS BIBLIOGRÁFICAS}

CMC, Ata da $46^{a}$ Sessão Ordinária, do $2^{o}$ Período Legislativo Ordinário, da $4^{a}$ Sessão Legislativa, da $15^{\text {a }}$ Legislatura, Realizada em: 20/11/2012 a

CMC, Ata da $47^{a}$ Sessão Ordinária, do $2^{\circ}$ Período Legislativo Ordinário, da $4^{a}$ Sessão Legislativa, da $15^{\text {a }}$ Legislatura, Realizada em: 21/11/2012 b

CMC, Ata da $48^{a}$ Sessão Ordinária, do $2^{o}$ Período Legislativo Ordinário, da $4^{a}$ Sessão Legislativa,

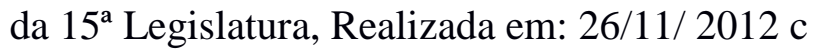

CMC, Ata da $49^{a}$ Sessão Ordinária, do $2^{\circ}$ Período Legislativo Ordinário, da $4^{a}$ Sessão Legislativa, da $15^{\text {a }}$ Legislatura, Realizada em: 27/11/ 2012 d

CMC, Ata da $4^{a}$ Sessão Ordinária, do $1^{o}$ Período Legislativo Ordinário, da $1^{a}$ Sessão Legislativa, da $16^{\mathrm{a}}$ Legislatura, Realizada em: 18/02/2013 a 
CMC, Ata da $18^{a}$ Sessão Ordinária, do $2^{\circ}$ Período Legislativo Ordinário, da $1^{a}$ Sessão Legislativa, da $16^{a}$ Legislatura, Realizada em: 11/09/2013 b

CMC, Ata da $39^{a}$ Sessão Ordinária, do $2^{\circ}$ Período Legislativo Ordinário, da $1^{a}$ Sessão Legislativa, da $16^{\text {a }}$ Legislatura, Realizada em: 05/11/2013 c

CMC, Ata da $40^{a}$ Sessão Ordinária, do $2^{\circ}$ Período Legislativo Ordinário, da $1^{a}$ Sessão Legislativa, da $16^{\text {a }}$ Legislatura, Realizada em: 06/11/2013 d

CMC, Ata da $43^{a}$ Sessão Ordinária, do $2^{o}$ Período Legislativo Ordinário, da $1^{a}$ Sessão Legislativa, da $16^{\text {a }}$ Legislatura, Realizada em: 13/11/2013 e

CMC, Ata da $44^{a}$ Sessão Ordinária, do $2^{o}$ Período Legislativo Ordinário, da $1^{a}$ Sessão Legislativa, da $16^{\text {a }}$ Legislatura, Realizada em: 18/11/2013 f

CMC, Ata da $16^{a}$ Sessão Ordinária, do $1^{o}$ Período Legislativo Ordinário, da $2^{a}$ Sessão Legislativa, da $16^{a}$ Legislatura, Realizada em: 19/03/2014 a

CMC, Ata da $42^{a}$ Sessão Ordinária, do $2^{o}$ Período Legislativo Ordinário, da $2^{a}$ Sessão Legislativa, da $16^{\text {a }}$ Legislatura, Realizada em: 10/11/2014 b

CMC, Ata da $45^{a}$ Sessão Ordinária, do $2^{o}$ Período Legislativo Ordinário, da $2^{a}$ Sessão Legislativa, da $16^{a}$ Legislatura, Realizada em: 17/11/2014 c

CMC, Ata da $46^{a}$ Sessão Ordinária, do $2^{o}$ Período Legislativo Ordinário, da $2^{a}$ Sessão Legislativa, da $16^{a}$ Legislatura, Realizada em: 18/11/2014 d

CMC, Ata da $47^{a}$ Sessão Ordinária, do $2^{\circ}$ Período Legislativo Ordinário, da $2^{a}$ Sessão Legislativa, da $16^{a}$ Legislatura, Realizada em: 19/11/2014 e

CMC, Ata da $44^{a}$ Sessão Ordinária, do $2^{o}$ Período Legislativo Ordinário, da $3^{a}$ Sessão Legislativa, da $16^{a}$ Legislatura, Realizada em: 18/11/2015 a

CMC, Ata da $45^{a}$ Sessão Ordinária, do $2^{o}$ Período Legislativo Ordinário, da $3^{a}$ Sessão Legislativa, da $16^{a}$ Legislatura, Realizada em: 23/11/2015 b

CMC, Ata da $47^{a}$ Sessão Ordinária, do $2^{o}$ Período Legislativo Ordinário, da $3^{a}$ Sessão Legislativa, da $16^{a}$ Legislatura, Realizada em: 25/11/2015 c

CMC, Ata da $32^{a}$ Sessão Ordinária, do $1^{o}$ Período Legislativo Ordinário, da $4^{a}$ Sessão Legislativa, da $16^{a}$ Legislatura, Realizada em: 20/04/2016 d

CMC, Ata da $38^{a}$ Sessão Ordinária, do $2^{\circ}$ Período Legislativo Ordinário, da $4^{a}$ Sessão Legislativa, da $16^{a}$ Legislatura, Realizada em: 07/11/2016 e

André Passos Proposição n ${ }^{\circ}$ 055.00054.2001 de 20/11/2001 Fonte: Sistema de Proposições Legislativas - SPLII . Disponível em: https://goo.gl/i2grGm>. Acesso em: 14/09/2016.

Reinhold Stephanes Jr - Proposição $n^{\circ}$ : 005.00295.2005 de 10/11/2005. Fonte: Sistema de Proposições Legislativas - SPLII Disponível em: https://goo.gl/UCBPN2. Acesso em: 14/09/2016.

Manassés Oliveira - Proposição nº 005.00279 .2006 de 20/11/2006 Fonte: Sistema de Proposições 
Legislativas - SPLII Disponível em: <https://goo.gl/91Lf5N>. Acesso em: 14/09/2016.

Renata Bueno - Proposição $n^{\circ}$ : 055.00027.2009 de 18/11/2009 Fonte: Sistema de Proposições Legislativas - SPLII Disponível em:<https://goo.gl/wpcj3i>. Acesso em: 14/09/2016.

Clementino Vieira - Proposição $n^{\circ}$ : 005.00148.2010 de 16/07/2010. Fonte: Sistema de Proposições Legislativas - SPLII Disponível em: <https://goo.gl/S5X3DP>. Acesso em: 14/09/2016.

Tico Kuzma - Proposição $n^{\circ}: 401.00024 .2012$ de 12/06/2012. Fonte: Sistema de Proposições Legislativas - SPLII Disponível em:〈https://goo.gl/vLa6gV>. Acesso em: 14/09/2016.

Tito Zeglin - Proposição $n^{\circ}$ : 005.00129.2012 de 20/11/2012. Fonte: Sistema de Proposições Legislativas - SPLII Disponível em:<https://goo.gl/36RqrR>. Acesso em: 14/09/2016.

Tito Zeglin Proposição $n^{\circ}$ : 005.00063.2013 de 05/02/2013. Fonte: Sistema de Proposições Legislativas - SPLII Disponível em:〈https://goo.gl/1WD8XK>. Acesso em: 14/09/2016.

Professor Galdino - Proposição $n^{\circ}$ : 005.00446 .2013 de 12/11/2013 Fonte: Sistema de Proposições Legislativas - SPLII Disponível em:<https://goo.gl/i6x4Da>. Acesso em: 14/09/2016.

Jorge Bernardi - Proposição $n^{\circ}$ : 302.00142.2013 de 02/12/2013 Fonte: Sistema de Proposições Legislativas - SPLII Disponível em: <https://goo.gl/ScHto9>. Acesso em: 14/09/2016.

Professora Josete - Proposição $n^{\circ}$ : 407.00022 .2013 de 22/11/2013 Fonte: Sistema de Proposições Legislativas - SPLII Disponível em: 〈https://goo.gl/PmWGxJ>. Acesso em: 14/09/2016.

Jorge Bernardi - Proposição $n^{\circ}$ : 067.00017.2014 de 17/08/2014 Fonte: Sistema de Proposições Legislativas - SPLII Disponível em:<https://goo.gl/gcnzyx>. Acesso em: 14/09/2016.

Chicarelli - Proposição 005.00048.2014 de 14/04/2014 Fonte: Sistema de Proposições Legislativas - SPLII Disponível em:<https://goo.gl/kXCH64>. Acesso em: 14/09/2016.

Jorge Bernardi - Proposição $n^{\circ}$ : 407.00009.2015 de 03/08/2015 Fonte: Sistema de Proposições Legislativas - SPLII Disponível em:〈https://goo.gl/m9fCyj>. Acesso em: 14/09/2016.

Marlene Zanin Fonte: Nossa Memória : História de Curitiba e da Câmara Municipal - Lista dos exvereadores de Curitiba, desde 1947. Disponível em: 〈https://www.cmc.pr.gov.br/galeria_ver.php〉. Acesso em: 14/02/2018.

Marlene Zanin Fonte: Blog do Zé Beto - As vereadoras de Curitiba. Disponível em: <http://www.zebeto.com.br/as-vereadoras-de-curitiba/\#.Wn5DAXTJ1pg>. Acesso em: 14/02/2018. André Passos Fonte: Instituto Edésio Passos - Quem Somos. Disponível em: <https://www.institutoedesiopassos.com.br/quem-somos >. Acesso em: 14/02/2018.

André Passos Fonte: Eleições \& Política - Eleições Municipais 2004. Disponível em: $<$ https://eleicoesepolitica.net/vereador2004/PR/75353/13131>. Acesso em: 14/02/2018.

Reinhold Stephanes Junior Fonte: Wikipédia. Disponível em: <https://pt.wikipedia.org/wiki/Reinhold_Stephanes_Junior>. Acesso em: 14/02/2018.

Reinhold Stephanes Junior Fonte: Assembleia Legislativa do Paraná - Reinhold Stephanes Junior. Disponível em: <http://www.alep.pr.gov.br/deputados/perfil/55-stephanes-junior> visto em: $14 / 02 / 2018$ 
Manassés Oliveira Fonte: Uol Notícia: Politicos do Brasil - Manassés Oliveira. Disponível em: $<$ https://noticias.uol.com.br/politica/politicos-brasil/2008/vereador/19061964-manassesoliveira.jhtm>. Acesso em: 14/02/2018.

Manassés Oliveira Fonte: Câmara Municipal de Curitiba: Notícias do Legislativo - Manassés Oliveira retorna à Câmara. Disponível em: $<$ https://cmc.pr.gov.br/ass_det.php?not=10912>. Acesso em: 14/02/2018.

Renata Bueno Fonte: Wikipédia Disponível em:〈https://pt.wikipedia.org/wiki/Renata_Bueno $\rangle$. Acesso em: 14/02/2018.

Tico Kusma Fonte: Câmara Municipal de Curitiba: Vereadores - Tico Kusma. Disponível em: <https://www.cmc.pr.gov.br/ver_det.php?ver=36>. Acesso em: 14/02/2018.

Tico Kusma Fonte: Eleições 2016 - Tico Kusma. Disponível em: <https://www.eleicoes2016.com.br/tico-kuzma/>. Acesso em: 14/02/2018.

Tito Zeglin Fonte: Gazeta do Povo: Eleições 2016 Guia dos Candidatos - Tito Zeglin. Disponível em: $\quad<$ http://www.gazetadopovo.com.br/vida-publica/eleicoes/2016/guia-candidatos/curitibapr/vereador/tito-zeglin-12345/>. Acesso em: 14/02/2018.

Tito Zeglin Fonte: Câmara Municipal de Curitiba: Notícias Do Legislativo - Vereador da capital é recordista mandatos cm consecutivos. Disponível <http://www.cmc.pr.gov.br/ass det.php?not=19713\#\&panel1-1>. Acesso em: 14/02/2018.

Tito Zeglin Fonte: The Cities Disponível em: <https://www.thecities.com.br/Brasil/Paran\%C3\%A1/Curitiba/Poder-P\%C3\%BAblico/PoderLegislativo-municipal/Mandato-2013-2016/Vereadores/Tito-Zeglin/2340/>. Acesso em: 14/02/2018.

Sabino Picolo Fonte: Eleições 2016. Disponível em:<https://www.eleicoes2016.com.br/sabinopicolo/>. Acesso em: 14/02/2018.

Sabino Picolo Fonte: Câmara Municipal de Curitiba: Vereadores - Sabino Picolo. Disponível em: <https://www.cmc.pr.gov.br/ver_det.php?ver=33>. Acesso em: 14/02/2018.

Sabino Picolo Fonte: Jornal Tribuna do Paraná. Disponível em: $<$ http://www.tribunapr.com.br/noticias/politica/curitiba-tem-milionarios-concorrendo-ao-cargo-devereador-veja-os-mais-ricos/ >. Acesso em: 14/02/2018.

Zezinho do Sabará Fonte: Eleições $2016 . \quad$ Disponível em: <https://www.eleicoes2016.com.br/zezinho-do-sabara/ > visto em: 14/02/2018

Zezinho do Sabará Fonte: Câmara Municipal de Curitiba: Vereadores- Zezinho do Sabará. Disponível em:< https://www.cmc.pr.gov.br/ver_det.php?ver=3492 >. Acesso em: 14/02/2018.

Gustavo Fruet Fonte: Wikipedia. Disponível em: $\langle$ https://pt.wikipedia.org/wiki/Gustavo_Fruet $>$. Acesso em: 14/02/2018.

Professora Josete Fonte: Eleições 2016. Disponível em: <https://www.eleicoes2016.com.br/professora-josete/ > . Acesso em: 14/02/2018.

Professora Josete Fonte: Blog do Zé Beto. Disponível em: < http://www.zebeto.com.br/asvereadoras-de-curitiba/\#.WpwuxcRv-mx >. Acesso em: 14/02/2018. 
Julieta Reis Fonte: Eleições 2016 . Disponível em: 〈https://www.eleicoes2016.com.br/julieta-reis/> . Acesso em: 14/02/2018.

João do Suco Fonte: Eleições 2016. Disponível em: <https://www.eleicoes2016.com.br/julieta-reis/>. Acesso em: 14/02/2018.

João do Suco Fonte: Câmara Municipal de Curitiba: Ex-Presidentes- João Luiz Cordeiro. Disponível em: <https://www.cmc.pr.gov.br/galeria.php?ano=2012 >. Acesso em: 14/02/2018.

Clementino Vieira Fonte: Blog do Campana. Disponível em: <http://www.fabiocampana.com.br/2010/04/clementino-vieira-na-secretaria-do-trabalho/>. Acesso em: 14/02/2018.

Algaci Tulio. Fonte: Portal G1:Vereador Algaci Túlio (PMDB) anuncia fim da carreira política após 30 anos. Disponível em: <http://g1.globo.com/pr/parana/noticia/2012/07/vereador-algaci-tuliopmdb-anuncia-fim-da-carreira-politica-apos-30-anos.html>. Acesso em: 14/02/2018.

Comissionados, empresários ou no desemprego: a vida dos ex-vereadores de Curitiba Fonte: Gazeta do Povo. Disponível em: <http://www.gazetadopovo.com.br/politica/parana/comissionadosempresarios-ou-no-desempregoa-vida-dos-ex-vereadores-de-curitiba-282si4b15372j9ct8eom439yr>. Acesso em: 14/02/2018.

Pedro Paulo Fonte: Gazeta do Povo: Guia dos Candidatos 2016- Pedro Paulo. Disponível em: <http://www.gazetadopovo.com.br/vida-publica/eleicoes/2016/guia-candidatos/curitibapr/vereador/pedro-paulo-12111/ > . Acesso em: 14/02/2018.

Pedro Paulo Fonte: Gazeta do Povo: Vereador Pedro Paulo (PT) é o líder do prefeito na Câmara de Curitiba. Disponível em: $<$ http://g1.globo.com/pr/parana/noticia/2013/01/vereador-pedro-paulo-pte-o-lider-do-prefeito-na-camara-de-curitiba.html >. Acesso em: 14/02/2018.

Noemia Rocha Fonte: Eleições 2016. Disponível em:<https://www.eleicoes2016.com.br/noemiarocha/> visto em: 14/02/2018.

Noemia Rocha Fonte: Blog do Zé Beto. Disponível em: $<$ http://www.zebeto.com.br/as-vereadoras-decuritiba/\#.WpwuxcRv-mx>. Acesso em: 14/02/2018.

Iris Simões Fonte: FGV-CPDOC - Centro de Pesquisa e Documentação História Contemporânea do Brasil. Disponível em: <http://www.fgv.br/cpdoc/acervo/dicionarios/verbete-biografico/simoes-iris $>$. Acesso em: 14/02/2018.

Iris Simões Fonte: Bonde: Iris Simões toma posse e anuncia fim da carreira política. Disponível em: $<$ https://www.bonde.com.br/bondenews/politica/iris-simoes-toma-posse-e-anuncia-fim-da-carreirapolitica-248665.html> visto em: 14/02/2018.

Jair Cezar Fonte: Wiki Adote um Vereador Disponível em: <http://vereadores.wikia.com/wiki/Jair_C\%C3\%A9zar >. Acesso em: 14/02/2018.

Jair Cezar Fonte: Gazeta do Povo: Guia dos Candidatos 2016- Disponível em: <http://www.gazetadopovo.com.br/vida-publica/eleicoes/2016/guia-candidatos/curitibapr/vereador/jair-cezar-20200/ >. Acesso em: 14/02/2018.
Jair
Cezar
Fonte:
Eleições
Uol 2016.
Disponível
em: 
<https://eleicoes.uol.com.br/2012/candidatos/2012/vereador/pr/05111939-jair-cezar.htm>. Acesso em: 14/02/2018.

Mario Celso Fonte: Eleições \& $\quad$ Politicas. Disponível em: $<$ https://eleicoesepolitica.net/vereador2008/PR/75353/40040 > visto em: 14/02/2018.

Mario Celso Fonte: Blog do Mario Celso. Disponível em: <http://www.mariocelso.com.br/quem.php $>$. Acesso em: 14/02/2018.

Cláudio Derosso Fonte: Wikipédia. Disponível em:< https://pt.wikipedia.org/wiki/Jo\%C3\%A3o_Cl\%C3\%A1udio_Derosso>. Acesso em: 14/02/2018.

Tiago Gevert Fonte: Gazeta do Povo: Guia dos Candidatos 2016 - Tiago Gevert. Disponível em: $<$ http://www.gazetadopovo.com.br/vida-publica/eleicoes/2016/guia-candidatos/curitibapr/vereador/tiago-gevert-20100/ > . Acesso em: 14/02/2018.

Jonny Stica Fonte: Wiki Adote um Vereador. Disponível em: <http://vereadores.wikia.com/wiki/Jonny_Stica $>$. Acesso em: 14/02/2018.

Jonny Stica Fonte: Gazeta do Povo: Guia dos Candidatos 2016 - Jonny Stica. Disponível em: $<$ http://www.gazetadopovo.com.br/vida-publica/eleicoes/2016/guia-candidatos/curitibapr/vereador/jonny-stica-12000/ >. Acesso em: 14/02/2018.

Hélio Wirbiski Fonte: Blog do Hélio Wirbiski. Disponível em: <http://www.heliowirbiski.com.br/sobre-mim>. Acesso em: 14/02/2018.

Pastor Valdemir Fonte: Eleições \& $\quad$ Politica $\quad$ Disponível em:<https://eleicoesepolitica.net/vereador2000/PR/75353/11698>. Acesso em: 14/02/2018.

Pastor Valdemir Fonte: Portal G1: Ex-vereador que votou por colega em Curitiba faz 'viagem missionária'. Disponível em: <http://g1.globo.com/pr/parana/noticia/2016/04/ex-vereador-quevotou-por-colega-em-curitiba-faz-viagem-missionaria.html>. Acesso em: 14/02/2018.

Chicarelli Fonte: Gazeta do Povo: Guia dos Candidatos 2016. Disponível em: <http://www.gazetadopovo.com.br/vida-publica/eleicoes/2016/guia-candidatos/curitibapr/vereador/chicarelli-27123/ >. Acesso em: 14/02/2018.

Ailton Araujo Fonte: Eleições Uol 2012. Disponível em: <https://eleicoes.uol.com.br/2012/candidatos/2012/vereador/pr/11051942-ailton-araujo.htm>. Acesso em: 14/02/2018.

Professor Galdino Fonte: Wiki Adote um Vereador. Disponível em: $\langle$ http://vereadores.wikia.com/wiki/Galdino>. Acesso em: 14/02/2018.

Professor Galdino Fonte: Wikiquote. Disponível em: <https://pt.wikiquote.org/wiki/Professor_Galdino>. Acesso em: 14/02/2018.

Professor Galdino Fonte: Jornal Tribuna do Paraná: Professor Galdino é suspenso de seu mandato de vereador em Curitiba. Disponível em: 〈http://www.tribunapr.com.br/noticias/politica/professorgaldino-e-suspenso-de-seu-mandato-de-vereador-em-curitiba/> . Acesso em: 14/02/2018.

SANCHES, M. A. O negro em Curitiba: a invisibilidade cultural do visível. Dissertação (Mestrado) 
- Universidade Federal do Paraná. Programa de Pós-Graduação em Antropologia. Curitiba, 1997.

SILVEIRA, Oliveira . 20 de Novembro: história e conteúdo. In: SILVA, P. B. G.; SISTEMA DE PROPOSIÇÕES LEGISLATIVAS $\quad-\quad$ SPLII

<http://www.cmc.pr.gov.br/wspl/system/MainMenu.jsp>. 